\title{
Customer Concentration of Targets in Mergers and Acquisitions*
}

\author{
Mei Cheng ${ }^{+}$ \\ University of Arizona \\ Jacob Jaggi \\ University of Arizona \\ Spencer Young \\ University of Arizona
}

November 2018

Please do not circulate without the authors' permission

\begin{abstract}
We study how customer base concentration at a target firm impacts the occurrence and structure of M\&A deals. We hypothesize that customer concentration increases information asymmetry and adverse selection between bidders and targets, such that (1) firms with greater customer concentration are less likely to receive a bid and (2) bidders for targets with greater customer concentration share the risk by using more stock payment in their offer. Using data on customer concentration and M\&A deals from 1985 to 2016, we find consistent evidence supporting our predictions. Our findings extend the literature by systematically documenting an important factor in M\&A decisions and by quantifying the economic consequences of customer concentration.
\end{abstract}

Keywords: customer concentration; business risk; mergers and acquisitions

JEL Classification: M41; G34

${ }^{*}$ We thank Michael Ettredge, Scott Judd, Aaron Nelson, and conference participants at the 2018 ASU-UA Accounting Research Conference and the 2018 BYU Accounting Research Symposium.

${ }^{+}$Corresponding author contact information: meicheng@email.arizona.edu 


\section{Customer Concentration of Targets in Mergers and Acquisitions}

\section{Introduction}

Customer concentration captures how a firm's revenue is distributed across its customers and the extent to which the firm relies on a small set of large customers. It is one of the most important firm characteristics of a firm's customer base. ${ }^{1}$ Because of the importance of customer concentration to the firm's risk and opportunities, Accounting Standards Codification 280-10 (formerly SFAS No. 131) requires firms to disclose information about their reliance on major customers which make up 10 percent or more of total firm sales. Customer concentration occurs frequently and can be significant. Approximately 45 percent of public firms report at least one major customer, and on average among manufacturing firms, one-third of sales is attributed to major customers (Ellis, Fee, and Thomas 2012; Campello and Gao 2017). Anecdotal evidence in M\&A literature suggests that customer concentration of potential targets is a significant risk factor for acquirers (Nead 2017; River's Edge 2014). However, there is little empirical evidence on how customer concentration of potential targets affects firms' investment decisions. In this study, we fill this void by systematically studying how target customer concentration impacts the occurrence and structure of M\&A deals.

Prior studies provide mixed views of the effects of customer concentration. On one hand, customer concentration signals heightened business risk and has been shown to increase the cost of equity and cost of debt (Kolay, Lemmon, and Tashjian 2016; Dhaliwal, Judd, Serfling, and Shaikh 2016; Campello and Gao 2017). On the other hand, some studies find that concentrated firms have higher rates of return due to greater operating efficiencies (Kalwani and Narayandas

\footnotetext{
${ }^{1}$ Forbes Magazine has noted that customer concentration risk is one of the biggest risks to business (Sutton and Nelson 2009).
} 
1995; Patatoukas 2012). In the M\&A setting, risk assessment of the target company is a key consideration for the acquiring firm (Dunn, Fontenot, and Loew 2018; Kohers and Ang 2000). Customer concentration increases uncertainty about a firm's future cash flows because a major customer may stop purchasing from the firm because of poor financial health or because of a decision to switch suppliers. Also, the change of control associated with a merger may heighten the risk of customers switching suppliers by disrupting customer-supplier relationships (Krug and Hegarty 2001). ${ }^{2}$ This uncertainty creates the potential for information asymmetry between the target and acquirer. Through interactions with major customers, the target acquires private relationship-specific information that improves its ability to forecast cash flows relative to the outside acquirer. This customer concentration-related asymmetry represents a risk to a potential acquirer who may alter the terms of the offer (including declining to make an offer) to decrease their exposure to this risk. With information asymmetry between the parties, the acquirer faces an adverse selection problem and may decide not to make an offer. We therefore first hypothesize that acquirers are less likely to make a bid offer for firms with greater customer concentration because of the information asymmetry regarding this risk. ${ }^{3}$

When deciding to make an offer, the acquiring firm obtains private information and assesses various aspects of target risks (Perry and Herd 2004). The information gathered via due diligence may to some degree decrease information asymmetry but does not fully eliminate information

\footnotetext{
${ }^{2}$ For example, Intintoli, Serfling, and Shaikh (2017) find that a change in a customer's CEO disrupts the customersupplier relationship such that suppliers lose substantial sales following the change.

${ }^{3}$ Our predictions are based on information asymmetry which arises through asymmetric uncertainty related to customer concentration. For several reasons, uncertainty on its own does not necessarily lead to the same predictions. First, if customer concentration-related uncertainty represents a risk that is apparent to both the target and the acquirer, the risk can be priced and the deal can occur. Second, the direction of the effect of demand uncertainty on an acquirer's investment decision is theoretically ambiguous and depends on many assumptions, including the risk attitudes of the acquirer, competition in product markets, and the anticipated costs of adjusting to a demand shock. (Guiso and Parigi 1999).
} 
asymmetry or the uncertainty related to concentrated customers. ${ }^{4}$ Conditional on a bid being offered, an acquiring firm has incentives to decrease its exposure to information asymmetryrelated risks. Hansen's (1987) adverse selection model suggests that when a target firm knows its value better than the acquirer does, the acquirer is more likely to pay with stock than cash, since payment in stock allows future declines in target value to be shared between the target firm and the acquirer. We therefore hypothesize that the proportion of payment offered in stock increases with the concentration of the target's customer base.

To test for the effects of target customer concentration on M\&A deals, we gather data on mergers and acquisitions over the years 1985 - 2016. We follow prior studies to define major customers as those that account for at least 10 percent of a supplier firm's total sales and measure customer concentration in three ways: an indicator variable for having at least one major customer, a sales-based Herfindahl Index, and the percentage of total sales attributable to major customers (Dhaliwal, Judd, Serfling, and Shaikh 2016; Huang, Lobo, Wang, and Xie 2016). ${ }^{5}$ We find that after controlling for other determinants of receiving a bid, potential target firms with a more concentrated customer base are less likely to receive a bid. Specifically, a firm with at least one customer that represents greater than ten percent of total sales has a 9 percent lower likelihood of receiving a bid than those that do not. Firms in the top decile of customer concentration have a 16 percent lower likelihood of receiving a bid than those in the bottom

\footnotetext{
${ }^{4}$ In addition to analyzing documents like customer agreements and customer satisfaction scores or related data, major customer due diligence can include conducting interviews and/or surveys of customers. We do not expect such due diligence to fully eliminate information asymmetry for several reasons. First, some deals include nondisclosure agreements that restrict the buyer's ability to contact customers (Harroch 2015). Second, even if contact does occur, major customers do not have incentives to disclose proprietary information about their supply chain relationships to a third-party. Third, the subjectivity of the relationships themselves makes them difficult for a thirdparty to ascertain or verify.

${ }^{5}$ We use the 10 percent cut off because Statement of Financial Accounting Standard No. 131 requires disclosure when sales to a customer account for 10 percent or more of the firm's total sales. In robustness tests, we also use a 20 percent cutoff, and find qualitatively similar results.
} 
decile of customer concentration. Furthermore, we find in the sample that receives bids, the proportion of payment offered in stock is higher when acquirers purchase targets with high customer concentration. Specifically, the proportion offered in stock is 12 percent higher (relative to the mean) for firms with at least one major customer. Stock-based payment is 22 percent higher for firms in the top decile of customer concentration compared to the bottom decile.

We conduct cross-sectional tests to provide further support for the impact of customer concentration on M\&A outcomes. First, we examine whether the effects of customer concentration differ when major customers are governmental or corporate. Compared to corporate customers, government entities are less likely to default and more likely to negotiate long-term contracts. These attributes of government entities decrease the uncertainty and information asymmetry regarding future cash flows. Consequently, we find that the effects of overall customer concentration on bid likelihood and payment method are driven mainly by corporate customer concentration. In contrast, governmental major customers have no impact on these M\&A outcomes.

Second, we expect that when a target's customers have low switching costs, the uncertainty and information asymmetry about losing the cash flow from those major customers is higher. Following prior studies, we measure switching costs using both the target firm's market share and the duration of the target's major customer relationships (Dhaliwal, Judd, Serfling, and Shaikh 2016; Irvine, Park, and Yildizhan 2016). We find evidence consistent with this prediction. When customers of potential target firms have low switching costs, the likelihood of receiving a bid is even lower and the proportion of payment offered in stock is higher. 
Third, acquiring a firm with stock is a viable risk-sharing strategy only when the acquired firm is sufficiently large relative to the bidder (Hansen 1987). Thus, we predict and find that the method of payment effects become more pronounced when the size of the target increases relative to that of the bidder. We find that the payment method effects are present only when customer concentration represents a salient risk (i.e., low switching costs) and when the risk sharing mechanism is available (i.e., the target is sufficiently large relative to the bidder).

Finally, we follow Dhaliwal, Judd, Serfling, and Shaikh (2016) in performing instrumental variable tests to alleviate the endogeneity concern that our results are driven by other target firm characteristics that correlate with measures of customer concentration. In two-stage tests, we find that predicted customer concentration remains negatively associated with bid likelihood and positively associated with payment method in stock.

Our study contributes to two streams of literature. First, we extend the M\&A literature by systematically documenting another important risk factor in M\&A decisions. Other risk factors that have been shown to affect M\&A deals include the target's country of domicile, culture, workforce stability, investment opportunities, etc. (Martin 1996; Bryson 2003; Cartwright and McCarthy 2005; Huang et al. 2016). Prior studies also find that target-firm financial reporting quality is significantly associated with various M\&A outcomes (Skaife and Wangerin 2013; Marquardt and Zur 2015). Our study extends this line of literature by documenting that target customer concentration reflects an important uncertainty about the firm with implications for information asymmetry and adverse selection. We extend prior M\&A literature on how information asymmetry affects the form of payment and the probability of receiving a bid (Dhaliwal, Lamoreaux, Litov, and Neyland 2016; Faccio and Masulis 2005; Palepu 1986; Uysal 2011). 
Second, our findings extend prior studies that examine the economic consequences of customer concentration. While several papers suggest that firms with a concentrated customerbase can have higher profits because of improved efficiencies (Kalwani and Narayandas, 1995; Patatoukas 2012), our findings suggest that the risk considerations manifest prominently in the M\&A market. Our paper relates to prior studies that document that customer concentration is associated with higher cost of equity, cost of debt and crash risk (Dhaliwal, Judd, Serfling, and Shaikh; Campello and Gao 2017; Chen, Hu, Meng, and Yao 2018). Our findings quantify the economic consequences of customer concentration in M\&A markets and may be of interest to practitioners who seek to understand how attributes of their customer bases impact their firms' prospects in M\&A markets.

The remainder of the paper proceeds as follows. The next section reviews the relevant literature and develops the hypotheses. Section 3 describes the research design and sample. Section 4 presents empirical results. Finally, Section 5 summarizes and concludes.

\section{Literature Review and Hypothesis Development}

\subsection{Prior Literature}

Prior literature takes two views of customer concentration. A supplier's relationships with major customers, while conventionally viewed as impeding supplier performance, may in some ways stimulate performance. The traditional 'impediment' viewpoint considers that major customers may exercise their relative bargaining power to extract concessions from suppliers, in the form of favorable trade terms including low prices (Galbraith 1952; River's Edge 2014). Major customers may also require significant relationship specific investments of their suppliers (Titman and Wessels 1988). On the other hand, recent literature also proposes an efficiency viewpoint. Suppliers with major customers may enjoy operating efficiencies that come with 
selling to major customers (Kalwani and Narayandas 1995) and may reap benefits by coordinating supply chain logistics with major customers (Kinney and Wempe 2002). Patatoukas (2012) investigates the net effect of customer concentration on suppliers' performance and finds some evidence of a causal link between customer concentration and higher accounting rates of return. Irvine et al. (2016) extends Patatoukas (2012) by showing empirical evidence that the effect of customer concentration on firm profitability depends on the life cycle of the relationship.

SFAS No. 131 (Codification 280-10) requires firms to disclose major customers because they signal high uncertainty about the supplier's future cash flow, and because firm-specific shocks along a supply chain can impact the performance of nearby firms in the chain (Hertzel, $\mathrm{Li}$, Officer, and Rodgers 2008; Kolay et al. 2016). Prior research studies how equity and credit markets evaluate firms' customer concentration. These studies estimate investors' perceptions of the net effect of all implications of customer concentration, including operating efficiency and risk. Dhaliwal, Judd, Serfling, and Shaikh (2016) document a positive association between customer concentration and cost of equity, suggesting that on average, equity investors perceive the risks associated with major customers as outweighing potential operating efficiencies. ${ }^{6}$ Campello and Gao (2017) find similar effects in bank lending: customer concentration increases interest rates and the number of restrictive covenants while reducing maturities. Chen et al. (2018) report a positive association between customer concentration and stock price crash risk. They find that firms with high customer concentration are more likely to disclose bad news. In

\footnotetext{
${ }^{6}$ Dhaliwal, Judd, Serfling, and Shaikh (2016) also find a positive association between customer concentration and
} bond yield spreads. 
summary, the literature provides not only evidence of customer concentration-related operational efficiencies, but also evidence of customer concentration-related risk consequences.

In a relevant paper, Harford, Schonlau, and Stanfield (2018) examine whether direct and indirect economic links between firms explain which firms are more likely to be involved in mergers. ${ }^{7}$ While the tests of Harford et al. (2018) are designed to capture the M\&A effects of economic relationships in supply chains, we examine the effects of customer concentration per se and how the information asymmetry and adverse selection problems that come with it manifest in bid likelihood and deal structure.

\subsection{Hypothesis Development}

Practitioner literature consistently highlights target customer concentration as one of the most important risk factors in M\&A. An undiversified customer base is viewed by potential acquirers as a significant risk for several major reasons. First, exposure to major customers brings potential for extreme cash flow problems after the deal is done (Nead 2017). Not only might major customers experience idiosyncratic shocks that disrupt liquidity at the potential target, but acquirers also worry that a change in ownership increases the likelihood that major customers defect entirely. Prior literature documents that many top managers depart shortly after an acquisition (Krug and Hegarty 2001). To the extent that personal connections facilitate major customer relationships, a change in control might lead to major customer turnover. Second, powerful major customers such as Walmart and $P \& G$ often dictate terms of the supply relationship, shrinking their suppliers' margins, and delaying payments. ${ }^{8}$ Both of these factors increase the uncertainty surrounding target firms' future cash flows. Finally, even if the acquirer

\footnotetext{
${ }^{7}$ Harford et al. (2018) find that firms with major customers are (1) more likely to receive bid offers from firms with direct or indirect trade relationships and (2) less likely to receive bid offers from firms without any trade relationship.

${ }^{8}$ A Wall Street Journal Article "Small firms' big customers are slow to pay" discusses these behaviors (Loten 2012).
} 
perceives a positive reward/risk tradeoff and is willing to pursue a deal with a potential target, there is no guarantee that equity sources and debt sources of financing will agree to facilitate the deal (River's Edge 2014). Together these concerns make customer concentration a first-order issue and potential deal-breaker as acquirers evaluate potential targets.

Prior literature shows that information asymmetry can influence acquisitions, including valuations, acquirer returns, payment method, and bid likelihood (e.g., Eckbo, Giammarino, and Heinkel 1990; Officer, Poulsen, and Stegemoller 2009; Krishnaswami and Subramaniam 1999; Officer 2004). Additionally, several papers show that the likelihood of being acquired increases when mechanisms to reduce information asymmetry function. For example, auditor quality is associated with a higher likelihood of a firm being acquired (Xie, Yi, and Zhang 2013) and firms are more likely to receive a bid from a firm that has the same auditor (Dhaliwal, Lamoreaux, Litov, and Neyland 2016). We believe that the uncertainty surrounding future major customer cash flows introduces information asymmetry that is also likely to affect the likelihood of receiving a bid.

Specifically, information asymmetry between the target firm and the acquiring firm causes the acquirer to estimate a wider range of expected future cash flows than the target. The target firm has a reservation price, which effectively creates a lower bound for a zone of possible agreement between the target and acquirer (Fishman 1989; Sebenius 1992). Any offer made by the acquirer must meet or exceed this threshold for a deal to occur. Information asymmetry may lead the acquirer to price protect and potentially fail to make an offer price that meets the target's reservation price. This price protection is exacerbated in the case where a firm has concentrated customers because the uncertainty of losing major customers increases the variance of future cash flows and the potential for information asymmetry. Therefore, we expect that all else equal, 
price discounting will be greater in the concentrated customer case. Because deeper price discounting decreases the likelihood that a bid will meet the target's reservation price, we expect that the likelihood of getting a bid will be lower. ${ }^{9}$

Furthermore, the empirical evidence of Dhaliwal, Judd, Serfling, and Shaikh (2016) and Campello and Gao (2017) suggests that debt and equity investors perceive customer concentration as a net risk. This evidence, along with the arguments above and anecdotal evidence suggesting that acquirers (and their sources of finance) carefully consider potential targets' customer concentration, leads us to hypothesize the following:

\section{H1: The likelihood that a firm receives a bid decreases with the concentration of its customer base.}

We note that the operating efficiency view of customer concentration can possibly lead to the opposite prediction. Specifically, if the acquirers weigh improved future profitability more than risk considerations, then they may prefer target firms with concentrated customers. This possibility adds tension to the hypothesis.

One important decision in structuring a merger or acquisition deal is the choice of exchange medium. Payment to target stockholders can be made in cash, in securities, or some combination thereof. Extensive prior literature examines the determinants of this choice, including tax and corporate control considerations, leverage, growth opportunities, corporate governance concerns, financing constraints, etc. (Amihud, Lev, and Travlos 1990; Carleton, Guilkey, Harris and Stewart 1983; Martin 1996; Uysal 2011; Faccio and Masulis 2005). The risk perceived by the acquirer also plays an active role in determining payment method. For example, Huang et al.

\footnotetext{
${ }^{9}$ It is natural to expect that acquirers of targets with customer concentration may systematically offer lower price premiums. However, the discounting may already be present in the stock price-that is, the stock price prior to the bid offer. We therefore do not focus on examining the price premium in the M\&A setting.
} 
(2016) find that acquirers are more likely to pay in stock when risk associated with cross-border mergers increases. The increased use of stock under risky conditions is consistent with acquirers sharing risk by using a payment method that is contingent upon the value created (Chi 1994).

Hansen (1987) models the transaction process of a merger or acquisition as a bargaining game with imperfect information. An adverse selection problem arises because the target knows its value better than the potential acquirer. This information asymmetry leads the acquirer to prefer stock as payment instead of cash, because of the contingent pricing characteristics of a stock payment. In other words, when the acquirer is less certain of the target's value (i.e. its future stream of cash flows), the acquirer is more likely to share the risk of acquiring the target by paying with stock, making the value of the consideration paid to the target contingent on the ongoing performance of target assets.

Because the uncertainty associated with customer concentration makes it harder for acquirers to assess the future cash flows of the target and its value, the acquirer is likely to protect against overpayment by paying with more stock relative to cash. Doing so effectively reduces the acquirer's exposure to risk because both acquirer and target share in the possible mispricing (Hansen 1987; Huang et al. 2016). We hypothesize the following:

H2: The proportion of the bid offer comprised of stock payment increases with the concentration of the target's customer base.

\section{Data and summary statistics}

\subsection{Sample selection}

We begin by obtaining bids and deal characteristics from Securities Data Corporation's Mergers and Acquisitions Database (SDC) from the beginning of 1985 through the end of 2016. We limit the sample to bids on public targets because we require stock returns and financial 
statement data for targets in our analysis. We also require that bidders own less than 50 percent prior to making an offer and seek to own more than 50 percent after the deal is completed (Dhaliwal, Lamoreaux, Litov, and Neyland 2016). These restrictions result in a base sample of 21,069 bids.

The unit of analysis for tests of our bid probability hypothesis is the firm-year. We obtain a sample of Compustat firm-years from 1985 - 2016, which we augment with data on stock returns from CRSP and institutional ownership from Thomson Reuters. We drop utilities (SIC 49004999) and financial firms (SIC6000 - SIC6999) and require data to calculate the target firm financial characteristics. These procedures yield a final sample of 108,430 firm-years, 8,448 of which exhibit a bid received. We refer to this sample as the 'bid sample' and use it to test our bid probability hypothesis.

The unit of analysis to test our payment method hypothesis is the bid offer. To craft a sample for these tests, we begin with the full sample of 21,069 bids described above, supplemented with the same set of financial characteristics of the target firm as well as additional deal-level data from SDC, including the method of payment used in the deal (i.e., the percent paid with stock). Requiring these data reduces the sample of bids available for payment method tests to 6,215 . We refer to this sample as the 'payment method sample'. Some tests require a measure of the size of the target relative to the acquirer. To accommodate these tests, we further restrict the sample of bids by requiring that the bidder be a public firm so that we can include a measure of relative size, along with other variables based on bidder financial characteristics. This requirement results in a sample of 2,310 bids. This we call the "public acquirer sample".

\subsection{Measures of customer concentration}


We follow prior literature in using multiple measures of customer concentration.

Specifically, we capture the degree to which sales to a small set of customers of a target (or potential target) firm is large relative to total sales (e.g., Dhaliwal, Judd, Serfling, and Shaikh 2016; Campello and Gao 2017; Patatoukas 2012). Beginning in 1976, accounting regulation required public companies to disclose if they supply customers that account individually for 10 percent or more of the supplier's revenue (ASC 280-10, FAS 131). ${ }^{10} \mathrm{We}$ obtain customer concentration data from Compustat's segment customer files. Our first measure of customer concentration is an indicator variable that is set to one if the target (or potential target) firm $i$ discloses a major customer in year $t$, and zero otherwise (MajorCustomer ${ }_{i t}$ ). Our second measure is based on an application of the Herfindahl-Hirschman Index, calculated following Dhaliwal, Judd, Serfling, and Shaikh (2016). ${ }^{11}$ This index takes values between 0 and 1, where higher values represent greater concentration of customers. We use the decile rank of the HHI index (CustomerHHI $\left.{ }_{i t}\right)$ as our second measure of customer concentration. We calculate our third measure (TotalMajorCustomerSales $i$ ) as the decile rank of the proportion of a target's (or potential target's) total annual sales that is accounted for by its major customers.

\subsection{Measures of bid probability and payment method}

We measure bid activity by specifying the variable BidIndicator $_{i t}$, which is equal to one if firm $i$ is announced as a target in a bid offer in year $t$, and zero otherwise. We measure payment method by specifying the variable PercentStock $k$, which, for each deal $k$ is equal to the portion of

\footnotetext{
${ }^{10}$ Some supplier firms voluntarily disclose major customers that account for less than $10 \%$ of sales. Because this voluntary choice could introduce self-selection bias, we do not include these customers in the various calculations of customer concentration.

${ }^{11}$ Specifically, The Herfindahl-Hirschman Index captures target $i$ 's customer concentration in year $t$ across its $n$ major customers, as follows: $C \quad H \quad I_{i i}=\sum_{n-1}^{N}\left(\frac{S}{S} \frac{s_{i 1}}{s_{i i}}\right)^{2}$.
} 
the deal value offered in bidder common stock divided by total deal value. Bids and payment method data are obtained from SDC, as described in Section 3.1.

\subsection{Summary statistics}

Table 1 Panel A presents descriptive statistics for the bid sample. The descriptive statistics for our customer concentration measures are similar to prior studies. ${ }^{12}$ In 37 percent of our observations, the target (or potential target) reports having at least one major customer. CustomerHHI and TotalMajorCustomerSales (in their unranked form) average 0.06 and 0.16, respectively. Among the set of observations with major customers, CustomerHHI and TotalMajorCustomerSales average 0.16 and 0.43 , respectively (untabulated). The average firmyear in our sample exhibits growth, slightly positive abnormal returns, MTB of 2.68, and a PE Ratio of 13.78. BidIndicator takes a mean value of 0.078 , which is comparable to prior studies (e.g., Cremers, Nair, and John 2008; Billett and Xue 2007). For detailed definitions of all variables, see the appendix.

Table 1 Panel B reports descriptive statistics for the payment method sample. The distributions of the customer concentration measures in this sample are similar to those in the bid sample. On average, 27 percent of deal value is offered in stock of the bidding firm, while 60 percent is offered in cash, which is comparable to prior studies (e.g., Martynova and Renneboog 2009; Karampatsas, Petmezas, and Travlos 2014). ${ }^{13}$ Relative to the total sample of firm-years in Panel A, firm-years with bids in Panel B tend to exhibit lower abnormal returns, MTB and PE

\footnotetext{
${ }^{12}$ Other studies using these measures include Patatoukas (2012); Dhaliwal, Judd, Serfling and Shaikh (2016); Huang et al. (2016); Irvine et al. (2016); and Campbell and Gao (2017).

${ }^{13}$ The remaining 13 percent of deal value is labeled by SDC as "other" (6 percent) and "unknown" (7 percent). Our variable Percent_Stock is the proportion of total deal value that is categorized as stock. In untabulated robustness tests, we define Percent_Stock as the proportion offered in stock scaled by the sum of the proportions offered in stock and cash. Our main payment method results are not sensitive to this choice.
} 
Ratios. For nearly half (47 percent) of bids in our sample, bidders and targets are in the same industry, and 13 percent of bids are contested, meaning multiple bids were received.

In Table 2, we report correlations among our measures of customer concentration, dependent variables and controls. In the bid sample (Panel A), the different measures of customer concentration are correlated with each other (Pearson correlations range from 0.51 to 0.83 ) and each measure is negatively correlated with the probability of receiving a bid. In the payment method sample, (Panel B), we observe no significant univariate correlation between customer concentration measures and the percent offered in stock. We examine these relations more fully in the following multivariate analysis.

\section{Multivariate analysis}

\subsection{Customer concentration and bid probability}

Our first tests address the relation between a firm's customer concentration and its likelihood of receiving a bid. We implement Logit regressions of the following general form:

$$
\operatorname{Pr}\left(B \quad r_{i 1}=1\right)=\alpha_{0}+\alpha_{1} C u s \quad n_{i 1}+X_{i 1} \beta+\beta_{j}+\beta_{t}+\varepsilon_{i 1}
$$

In this model, BidIndicator $i t$ is equal to one for a firm-year if the firm received a bid as reported by SDC (and zero otherwise), and CustomerConcentration ${ }_{i t}$ is one of three measures discussed in Section 3.2: MajorCustomer, CustomerHHI, or TotalMajorCustomerSales. Customer concentration measures and financial control variables are calculated using the most recent financial statement data disclosed prior to the bid announcement date. $X_{\mathrm{it}}$ is a set of controls for additional determinants of the probability of receiving a bid, as implemented by Dhaliwal, Lamoreaux, Litov, and Neyland (2016) and Palepu (1986). We include AbnormalReturn and $R O E$ to proxy for managerial effectiveness because acquisitions can be a market mechanism to replace inefficient managers. Palepu (1986) also suggests that firms are 
likely targets when they exhibit mismatch between their growth and resources at their disposal. The indicator GrowthMismatch is equal to one when a firm is low-growth but resource rich, and when a firm is high-growth but resource poor. ${ }^{14}$ We also control for Growth, measured using a three-year average change in sales. Because the costs associated with an acquisition increase with the size of the target, we control for target Size using total assets. We include Liquidity and Leverage to proxy for financial constraints of the target. MTB and PERatio proxy for the value of the target. We also include InstitutionalOwnership to control for ownership of the target as a determinant of bid likelihood. Finally, we include industry $\left(\beta_{j}\right)$ and year $\left(\beta_{t}\right)$ fixed effects to control for variation in bids by industry and over time. See the appendix for specific variable definitions.

Table 3 presents the results of this analysis. Columns 1-3 report the results of Logit regressions of BidIndicator on each of the three customer concentration variables and controls. To aid interpretation, we transform CustomerHHI and TotalMajorCustomerSales into decileranked variables in all multivariate analyses. ${ }^{15}$ In each column, the coefficient on CustomerConcentration is negative and statistically significant $(p<0.01)$, suggesting a reliably negative relation between a potential target's customer concentration and its likelihood of receiving a bid. These results are consistent with the hypothesis that the information asymmetry associated with a potential target's customer concentration decrease the likelihood of receiving a bid.

\footnotetext{
${ }^{14}$ We follow Dhaliwal, Lamoreaux, Litov, and Neyland (2016) in calculating this variable. Specifically, GrowthMismatch equals one for firm-years that exhibit either (1) above-median leverage and growth, but below-median liquidity, or (2) below-median leverage and growth, but above-median liquidity.

${ }^{15}$ CustomerHHI and TotalMajorCustomerSales are ranked in deciles so that for each observation, these variables take a value of an integer from 0 to 9 .
} 
In un-tabulated analysis, we compute marginal effects to provide economic significance of these results. The marginal effect of MajorCustomer (having at least one major customer) is -0.0073. Relative to the sample mean of BidIndicator, this represents a 9.4 percent decrease in the probability of receiving a bid. We compute the economic significance of CustomerHHI and TotalMajorCustomerSales by comparing the bottom decile to the top decile. Relative to the sample mean of BidIndicator, a shift from decile 1 to 10 represents a decrease in the probability of receiving a bid of 17.9 percent and 16.6 percent, respectively. ${ }^{16}$

\subsection{Customer concentration and method of payment}

The negative relation between customer concentration and the likelihood of receiving a bid suggests that bidders perceive potential targets' customer concentration as a risk. We next examine whether bidders seek to share the risk with the target by adjusting their method of payment. By financing the deal with common stock, bidders can effectively apportion the riskiness of the deal among the shareholders of the bidder and the target. ${ }^{17}$ To provide evidence on whether bidders employ this risk-sharing mechanism, we examine the relation between our measures of a target's customer concentration and the proportion of the deal value the bidder offers in common stock. We implement versions of the following general OLS regression:
$P_{1}$
$k_{i 1}=\alpha_{0}+\alpha_{1} C$
$n_{i 1}+X_{i 1} \beta+X_{k} \beta+\beta_{j}+\beta_{t}+\varepsilon_{i 1}$

\footnotetext{
${ }^{16}$ The marginal effect (un-tabulated) of CustomerHHI is -0.0016. Since CustomerHHI is decile-ranked, this is multiplied by 9 to obtain the marginal effect of a shift from decile 1 to decile $10(-0.0016 * 9=-0.0140)$. We compare this total marginal effect to the sample mean of BidIndicator to determine economic significance (-0.0140 / $0.078=-0.179)$. The same methodology is used to calculated economic significance of TotalMajorCustomerSales. ${ }^{17}$ Bidders can address the risk of mis-valuation using other contractual measures, including earnout clauses, which defer a portion of the merger payment and make it contingent on the target meeting prespecified performance standards. However, earnout clauses are much more feasible and prevalent in acquisitions of private firms than public firms, because negotiating a contract on ex post performance is much easier when there are one or a few sellers (Kohers and Ang 2000). In our sample of 6,215 bids for public targets, we observe only 27 with earnout values (less than 0.5 percent) and thus do not test whether customer concentration increases the occurrence of earnouts.
} 
In this model, PercentStock $k_{i t}$ is the portion of the value of deal $k$ offered using bidder common stock. CustomerConcentration ${ }_{i t}$ for target firm $i$ is measured as of the fiscal year-end $(t)$ immediately preceding the announcement of deal $k$ using one of the three measures described previously. $X_{\mathrm{it}}$ and $X_{\mathrm{k}}$ represent target-level and deal-level control variables, respectively. Since the factors driving the decision to place a bid may also affect the terms of the bid, we include in Equation (2) each of the control variables from Equation (1). We augment these controls with additional variables that have been shown to affect the method of payment in acquisitions, following the payment method model of Uysal (2011). Specifically, we include ReturnVolatility, SameIndustry, and CompetedBid. ${ }^{18}$ Finally, we include industry $\left(\beta_{\mathrm{j}}\right)$ and year $\left(\beta_{\mathrm{t}}\right)$ fixed effects.

Table 4, Panel A presents the results of OLS regressions of PercentStock on target customer concentration measures. When using the sample of 6,215 bids obtained as described in Section 3.1, we observe positive and significant coefficients on all three measures of target customer concentration $(p<0.01)$. These results are consistent with the hypothesis that the information asymmetry and mis-valuation risk associated with a target's customer concentration lead acquirers to prefer stock payment. In terms of economic significance, the proportion of the deal paid in stock is 3.2 percentage points higher when the target has at least one major customer. This represents an increase of 12.2 percent relative to the sample mean of PercentStock. In column two, the coefficient on CustomerHHI is 0.617 , representing the average effect on payment method of a one-decile increase in CustomerHHI. A shift from decile 1 to 10 of CustomerHHI represents an increase of 20.9 percent relative to the sample mean of PercentStock (the corresponding estimate for TotalMajorCustomerSales is 22.6 percent).

\footnotetext{
${ }^{18}$ In the smaller sample of bids (in Table 4, Panel B) from public bidders we also include AcquirerSales, AcquirerROA, AcquirerMTB, and RelativeSize.
} 
Notwithstanding the on-average results in Table 4, Panel A, we expect the relation between target customer concentration and the proportion of the deal paid in stock to vary based on the size of the target relative to the size of the acquirer. For the value of stock consideration to be contingent on the performance of the combined firm (and thus for stock payments to function as a viable risk-sharing mechanism), the assets and operations acquired must amount to a significant portion of the new, combined firm. As such, we expect the overall effect of customer concentration in Panel A of Table 4 to be stronger when the relative size of the target is greater. To test this expectation, we supplement Equation (2) with RelativeSize and its interaction with CustomerConcentration. ${ }^{19}$ Since the calculation of RelativeSize requires assets of the bidder, the sample for these tests is restricted to 2,310 deals with public bidders for which we have financial data. In these tests, we also control for additional bidder characteristics, following Uysal (2011).

Relative size results are reported in Panel B of Table 4. The main effect of customer concentration (i.e., when RelativeSize $=0$ ) is insignificant in all three tests, suggesting that when targets are very small relative to bidders, customer concentration shares no relation with the method of payment. Coefficients on RelativeSize are positive and significant in each column, consistent with the size of the target impacting payment method when customer concentration is negligible. The interactions between RelativeSize and CustomerConcentration measures are all positive and significant $(p<0.05)$, which is consistent with bidders using payment in stock as a mechanism to share customer concentration-related risk when the option is viable (i.e., when targets are sufficiently large). CustomerConcentration has a much greater economic impact on the percent paid in stock when interacted with RelativeSize. In column 1, the total effect of

\footnotetext{
${ }^{19}$ RelativeSize is calculated as the ratio of target assets to bidder assets, then ranked in deciles and scaled to range from 0 to 1 .
} 
CustomerConcentration is 7.582 , which represents a 28.6 percent increase relative to the sample mean of PercentStock. In columns 2 and 3, a shift from decile 1 to 10 of CustomerHHI represents an increase of 51.7 percent relative to the sample mean of PercentStock (the corresponding estimate for TotalMajorCustomerSales is 55.9 percent).

\subsection{Cross-sectional tests}

In this section, we report the results of cross-sectional tests showing variation in the relation between (potential) targets' customer concentration and bid outcomes. Specifically, we examine whether the main relations we document in Table 3 and Table 4 are stronger when customer concentration results in greater uncertainty and information asymmetry. We do this in two sets of tests. First, we identify the major customers of targets in our sample as government and nongovernment entities so that we examine the two components of customer concentration separately (e.g., Dhaliwal, Judd, Serfling, and Shaikh 2016). Second, we examine the effect of target customer concentration given variation in the major customers' switching costs. We proxy for switching costs using the target firm's market share (e.g., Dhaliwal, Judd, Serfling, and Shaikh 2016) and the length of major customer relationships (e.g., Irvine et al. 2016).

\subsubsection{Governmental and non-governmental concentration}

The concentration of a firm's customer base is important in assessing the risks inherent in the target firm's future cash flows, affecting uncertainty and thus the information asymmetry between a bidder and target. We expect this concentration-related uncertainty and information asymmetry to vary with the stability and predictability of cash flows from major customers. Our first cross-sectional tests consider the possibility that governmental major customers represent a more stable stream of cash flows than do non-governmental major customers. Government entities are less prone to financial distress that disrupts their purchasing and often deal in long- 
term contracts which provide assurance around near-term cash flows. Furthermore, the bureaucracy of government entities makes them less likely to switch suppliers. For these reasons, we expect less uncertainty and information asymmetry vis-à-vis a target's customer concentration if the target's major customers are government entities. To test this question, we estimate bid probability and payment method models replacing the overall customer concentration measures with its components: Govt_Concentration and NonGovt_Concentration. ${ }^{20}$

The results in Panel A of Table 5 show that the negative on-average relation between customer concentration and bid probability documented previously is concentrated among potential targets with non-government concentration $(p<0.01)$. In contrast, each of the coefficients on Govt_Concentration is statistically indistinguishable from zero. In each column, the coefficient on NonGovt_Concentration is significantly more negative than the coefficient on Govt_Concentration $(p<0.10)$.

A similar story emerges in the payment method tests reported in Panel B of Table 5. The positive relation between customer concentration and the proportion of bid offers consisting of stock payment is concentrated among bids for targets with non-government concentration $(p<$ 0.01). In contrast, each of the coefficients on Govt_Concentration is statistically indistinguishable from zero. The results of t-tests comparing the coefficients on NonGovt_Concentration and Govt_Concentration indicate that NonGovt_Concentration has a

\footnotetext{
${ }^{20}$ Customers are identified as government entities if Compustat categorizes them as such (i.e., if customer type equals GOVDOM, GOVFRN, GOVLOC, or GOVSTATE). We also consider observations with customer type equal to "COMPANY" but whose names contain one or more of the following key words: Army, Govts, Govt, Government, Governments, Federal, Defense, Department, Dept, Medicaid, Medicare, United States, and US. We manually verify that sixty-five of these organizations are fully-owned by governmental entities and identify them as such in our analysis.
} 
significantly greater impact on payment method than Govt_Concentration (at marginal statistical significance $(p=0.11))$.

As discussed in Section 4.2, the size of the target relative to the bidder determines the degree to which stock payment is a significant risk sharing mechanism. To further examine the effects of government and non-government customer concentration on payment method, we interact Govt_Concentration and NonGovt_Concentration with RelativeSize (using the public acquirer sample of 2,310 bids). As reported in Panel C of Table 5, we observe much stronger effects when relative size is high. Specifically, when RelativeSize $=1$ (i.e., in the top decile), the total effect of NonGovt_Concentration on payment method is significantly greater than the total effect of Govt_Concentration $(p<0.05)$.

We interpret the results of Table 5 as evidence that the overall negative (positive) relation between customer concentration and bid likelihood (payment method) is driven exclusively by corporate, non-governmental major customers. The reduced uncertainty and information asymmetry surrounding future cash flows of major government customers appear to minimize bidders' concerns.

\subsubsection{Switching costs using target market share}

Our second set of cross-sectional tests examine the implications of the barriers that major customers face to switching suppliers. When costs to a customer of switching suppliers are lower, the likelihood that the customer will switch is higher. This higher customer switch risk makes cash flows from major customers less reliable. We expect bidders to consider switching costs of major customers when evaluating the uncertainty associated with targets' customer concentration. Specifically, when switching costs are low, we expect a stronger negative (positive) relation between customer concentration and bid likelihood (payment with stock). 
To test these predictions, we first follow Dhaliwal, Judd, Serfling, and Shaikh (2016) in capturing customer switching costs by using supplier sales to measure industry market share. ${ }^{21}$ We measure SwitchingCosts as the fraction of the supplier's total industry sales that is captured by the supplier. Higher market shares (higher values of SwitchingCosts) indicate situations when customers face more difficulty in switching suppliers. We supplement Equations (1) and (2) with the SwitchingCosts variable and its interaction with CustomerConcentration and report results in Panels A and B of Table 6.

Results in Panel A of Table 6 show that switching costs play a significant role in our bid probability setting. The interaction of CustomerConcentration and SwitchingCosts $\left(v_{3}\right)$ is positive and significant in each model $(p<0.01)$. This finding suggests that when potential targets have captive major customers, the uncertainty and information asymmetry vis-à-vis the associated cash flows is low, which attracts bidders. On the other hand, when switching costs are low, customer concentration exhibits a strong negative relation with BidIndicator. Furthermore, the sum of coefficients on customer concentration and the interaction (i.e., the total effect of customer concentration, or $\left.v_{1}+v_{3}\right)$ is consistently positive and significant $(p<0.01)$. This result suggests that when uncertainty and information asymmetry surrounding cash flows from major customers attenuate (when the major customers are highly unlikely to switch suppliers), the stability of major customer cash flows makes firms attractive targets.

We report switching cost analyses in our payment method setting in Table 6, Panel B. When switching costs are low we observe a strong positive relation between customer concentration and stock-based payment (i.e., a positive main effect of CustomerConcentration $\left[\delta_{1}\right], p<0.01$ ).

\footnotetext{
${ }^{21}$ We use market share as a proxy for switching costs on the intuition that when a supplier has low industry market share, more alternative suppliers are available to its customers.
} 
However, inconsistent with our prediction, both the interaction of CustomerConcentration and SwitchingCosts $\left(\delta_{3}\right)$ and the total effect of CustomerConcentration when switching costs are high $\left(\delta_{1}+\delta_{3}\right)$ are insignificant. Given the importance of the target's relative size in determining payment method, we next augment the model with RelativeSize and its two- and three-way interactions with CustomerConcentration and SwitchingCosts (using the public acquirer sample of 2,310 bids). As reported in Panel $\mathrm{C}$ of Table 6, we observe that conditional on relative size being high, the relation between CustomerConcentration and PercentStock is positive when switching costs are low (e.g., the total effect of MajorCustomer when relative size is in the top decile but switching costs is in the bottom decile $\left[\tau_{1}+\tau_{4}\right]$ is $\left.17.842, p<0.01\right)$ and negative and insignificant when switching costs are high (e.g., the total effect of MajorCustomer when relative size is in the top decile and switching costs is also in the top decile $\left[\tau_{1}+\tau_{4}+\tau_{5}+\tau_{7}\right]$ is $-3.301, p$ $=0.65)$. Furthermore, when relative size is high, the difference between the effects of customer concentration under high and low switching costs is statistically significant (e.g., in column 1 , [ $\tau_{5}$ $\left.\left.+\tau_{7}\right]=-21.143, p<0.10\right)$.

In summary, our target market share analyses yield evidence that the negative relation between target customer concentration and bid probability is strengthened when the targets' customers face low barriers to switching suppliers. Also, the positive relation between target customer concentration and the proportion of payment made in stock is concentrated in the sample where switching costs are low and relative size is high.

\subsubsection{Switching costs using relationship age}

Irvine et al. (2016) argue that the effects of customer concentration vary with the maturity of major customer relationships, reporting evidence that the relation between customer concentration and profitability is negative in the early years of the relationship but positive in 
later years. In related literature, supplier-customer relationship age is also used as a proxy for relationship specific investment (RSI) and switching costs (e.g., Banerjee, Dasgupta, and Kim 2007; Brown, Fee, and Thomas 2009; Intintoli, Serfling, and Shaikh 2017). Customers and suppliers in long-term relationships are more likely to have made investments specific to the relationship, which increases the costs to the customer of switching to a new supplier.

If switching costs indeed increase with the maturity of major customer relationships, we expect the likelihood of receiving a bid to vary negatively with target customer concentration in the early years of the relationship and less negatively as the relationship matures. ${ }^{22}$ To test this prediction, we estimate the bid probability method models replacing the overall customer concentration measures with its components: CustomerConcentration_Long and

\section{CustomerConcentration_Short. ${ }^{23}$}

The results in Panel A of Table 7 show that the negative on-average relation between customer concentration and bid probability documented previously is concentrated among potential targets with short major customer relationships $(p<0.05)$. In contrast, each of the coefficients on CustomerConcentration_Long is significantly positive $(p<0.10)$. In each column, the coefficient on CustomerConcentration_Short is significantly more negative than the

\footnotetext{
${ }^{22}$ Relationship age may also proxy for the degree of information asymmetry between bidder and target that derives from major customer relationships. In the early years of a supply relationship, the public (and any potential acquirer) has very little information regarding the longevity of the major customer relationship, while the target's information set includes private communications and agreements with the major customer as to the RSIs undertaken by each party. As the relationship matures however, RSIs are incurred and the likelihood that the relationship fails decreases. The public infers relatively more information regarding the future stability of the relationship from its historical stability. This improvement in public inference reduces the information asymmetry between bidder and target (which results in the same prediction for our tests as the switching costs approach).

${ }^{23}$ To calculate CustomerConcentration_Long and CustomerConcentration_Short we measure the number of consecutive years that the target has disclosed a relationship with each major customer. Customers that have had a relationship for an above median number of consecutive years are used to calculate CustomerHHI_Long, MajorCustomer_Long, and TotalMajorCustomerSales_Long, else they are used to calculate CustomerHHI_Short, MajorCustomer_Short, and TotalMajorCustomerSales_Short.
} 
coefficient on CustomerConcentration_Long $(p<0.01)$. This pattern of results suggests that when major customer relationships are new, firms are less likely to receive a bid, but as those relationships mature, the negative association between customer concentration and bid likelihood attenuates. When major customer relationships are mature and customer concentration is high, the uncertainty and information asymmetry surrounding major customer cash flows is low and the stability of these significant cash flows makes firms attractive as targets.

A similar pattern emerges in the payment method tests reported in Panel B of Table 7. The positive relation between customer concentration and payment in stock is concentrated among bids for targets with short major customer relationships $(p<0.01)$. In contrast, each of the coefficients on CustomerConcentration_Long is statistically indistinguishable from zero. The results of t-tests comparing the coefficients on CustomerConcentration_Short and CustomerConcentration_Long indicate that directionally, short major customer relationships have a greater impact on payment method than mature major customer relationships (albeit only statistically significant under one-tailed tests in column 1$).{ }^{24}$

\subsection{Instrumental variables regressions}

In this section we address the possibility that unobserved omitted variables drive the relations we observe. For example, targets with high customer concentration may tend to also exhibit other business risks which themselves could drive some of our results. We address this concern by controlling for endogeneity in an instrumental variables framework, instrumenting for customer concentration using two- and three-year lagged industry averages of customer

\footnotetext{
${ }^{24}$ In untabulated analyses we augment the model with RelativeSize and its two- and three-way interactions with CustomerConcentration and SwitchingCosts. In this triple-interaction model, the difference between the total effects of long and short customer concentration is statistically insignificant.
} 
concentration. ${ }^{25}$ In utilizing these instrumental variables, we apply the intuition of Dhaliwal, Judd, Serfling and Shaikh (2016), who argue that, in their setting, the lagged industry averages of customer concentration satisfy both the relevance condition and exclusion restriction required of valid instruments. Analogously, in our M\&A models, validity of these instruments hinges on (1) their relevance to the customer concentration variables and (2) their correlation with bid probability and payment method only through the customer concentration variables (i.e., not correlated with the error terms).

By capturing the structure of customers by industry, average industry customer concentration should be highly correlated with an individual target's customer concentration, satisfying the relevance condition. Furthermore, lagged industry customer concentration is unlikely to be correlated with current bid probability and payment method (except through an individual target's customer concentration) because acquirers value potential targets and structure their bid offers based on estimates of future cash flows. Thus, lagged industry values likely satisfy the exclusion restriction.

Panel A of Table 8 presents the first-stage of the instrumental variables approach in our bid likelihood tests. Specifically, we report results of regressing each of our customer concentration variables on its two- and three-year lagged industry averages, including the controls from Table 3. We conduct several tests of the validity of our instruments. Low $p$-values in the Hausman specification tests $(p<0.01)$ reject the null that the customer concentration variables are exogenous on their own. High partial $\mathrm{R}^{2} \mathrm{~s}$ and $F$-statistics indicate the strength of our instruments (relevance to customer concentration). High $p$-values in the Sargan-Hansen tests $(p>0.23)$

\footnotetext{
${ }^{25}$ We follow Dhaliwal, Judd, Serfling, and Shaikh (2016) in using lagged industry averages of customer concentration as instrumental variables and in calculating industry averages using 3-digit SIC. The target's customer concentration is excluded from the calculation.
} 
indicate that we are unable to reject the null that our instruments are uncorrelated with the error term (exclusion restriction). Results of the second stage regressions, presented in Panel B of Table 8 , indicate a strong negative relation between predicted customer concentration and the likelihood of receiving a bid.

Panel A Table 9 presents the first-stage regressions of the instrumental variables approach in our payment method tests. We again observe high partial $\mathrm{R}^{2} \mathrm{~s}$ and $F$-statistics, along with insignificance in the Sargan-Hansen tests. These results bolster the validity of our instruments. In the $\mathrm{Wu}$-Hausman tests, we observe $p$-values marginally higher than 0.10 (but less than 0.22 ) and cannot reject the null that customer concentration variables are exogenous to begin with. However, to address remaining concerns that our results are driven by endogeneity we proceed with second-stage analysis. The results, presented in Panel B, indicate a strong positive relation between predicted customer concentration and the proportion of the deal paid for using stock.

In summary, to the extent that our instrumental variables satisfy the validity requirements, we interpret our results as evidence of a causal negative (positive) relation between target customer concentration and the probability of receiving a bid (the proportion of the deal offered in acquirer common stock).

\section{Conclusion}

Anecdotal evidence suggests that in M\&A markets, acquirers carefully consider the customer concentration of potential target firms, counting information related to customer concentration as "crucial and telling" (e.g., Wagner 2017). Acquiring a target with major customers can potentially bring operating efficiencies and significant cash flows, but such a target also comes with significant uncertainty, as major customers may elect to switch suppliers or experience distress that disrupts their buying behavior. This uncertainty introduces information asymmetry 
between the acquirer and target, because the target amasses private information through its relationships with major customers. Consistent with this asymmetry, we report evidence that firms with greater customer concentration are less likely to receive a bid, and that conditional on making a bid offer, bidders for targets with greater customer concentration share the risk by paying more with stock (so that the value of the offer is contingent on the long-run success of the deal). Our findings are robust to endogeneity tests using instrumental variables.

We also find that our results vary in cross-sections of firms for which customer concentration results in more or less uncertainty and asymmetry. First, the negative (positive) relation between target customer concentration and bid likelihood (proportion paid in stock) only exists for corporate major customers - relatively more stable government customers have no impact on these M\&A outcomes. Second, the effect of customer concentration on payment method is stronger when the target is sufficiently large relative to the acquirer, making stock payment viable as a risk-sharing mechanism. Third, the bid likelihood and payment method results are even stronger when the target's customers have low costs of switching suppliers. By quantifying the economic consequences of customer concentration, our findings provide useful insights to practitioners who seek to understand how attributes of their customer bases impact their firms' prospects in M\&A markets. 


\section{References}

Amihud, Y., Lev, B., \& Travlos, N. (1990). Corporate Control and the Choice of Investment Financing: The Case of Corporate Acquisitions. The Journal of Finance, 45(2), 603-616.

Banerjee, S., Dasgupta, S., \& Kim, Y. (2004). Buyer-Supplier Relationships and Trade Credit. Working Paper, Lancaster University.

Billett, M. T., \& Xue, H. (2007). The Takeover Deterrent Effect of Open Market Share Repurchases. The Journal of Finance, 62(4), 1827-1850.

Brown, D. T., Fee, C. E., \& Thomas, S. E. (2009). Financial leverage and bargaining power with suppliers: Evidence from leveraged buyouts. Journal of Corporate Finance, 15(2), 196211.

Bryson, J. (2003). Managing HRM risk in a merger. Employee Relations, 25(1), 14-30.

Campello, M., \& Gao, J. (2017). Customer concentration and loan contract terms. Journal of Financial Economics, 123(1), 108-136.

Carleton, W., Guilkey, D., Harris, R., \& Stewart, J. (1983). An Empirical Analysis of the Role of the Medium of Exchange in Mergers. The Journal of Finance, 38(3), 813-826.

Cartwright, S., \& McCarthy, S. (2005). 11 Developing a Framework for Cultural Due Diligence in Mergers and Acquisitions. In Mergers and acquisitions: Managing culture and human resources (p. 253).

Chen, Y., Hu, G., Meng, C., \& Yao, J. (2018). Customer Concentration and Stock Price Crash Risk. Working Paper.

Chi, T. (1994). Trading in strategic resources: Necessary conditions, transaction cost problems, and choice of exchange structure. Strategic Management Journal, 15(4), 271-290.

Cremers, K. J. M., Nair, V. B., \& John, K. (2009). Takeovers and the cross-section of returns. Review of Financial Studies, 22(4), 1409-1445.

Dhaliwal, D., Judd, J. S., Serfling, M., \& Shaikh, S. (2016). Customer concentration risk and the cost of equity capital. Journal of Accounting and Economics, 61(1), 23-48.

Dhaliwal, D., Lamoreaux, P. T., Litov, L. P., \& Neyland, J. B. (2016). Shared auditors in mergers and acquisitions. Journal of Accounting and Economics, 61(1), 49-76. 
Dunn, G., Fontenot, L. A., \& Loew, B. W. (2016). Risk management in M\&A transactions. Retrieved July 9, 2018, from https://www.gibsondunn.com/wpcontent/uploads/documents/publications/FontenotLoewRiskManagementinMATransactions.pdf.

Eckbo, B. E., Giammarino, R. M., \& Heinkel, R. L. (1990). Asymmetric Information and the Medium of Exchange in Takeovers: Theory and Tests. The Review of Financial Studies, $3(4), 651-675$.

Ellis, J. A., Fee, C. E., \& Thomas, S. E. (2012). Proprietary Costs and the Disclosure of Information About Customers. Journal of Accounting Research, 50(3), 685-727.

Faccio, M., \& Masulis, R. W. (2005). The Choice of Payment Method in European Mergers and Acquisitions. The Journal of Finance, 60(3), 1345-1388.

Fishman, M. J. (1989). Preemptive Bidding and the Role of the Medium of Exchange in Acquisitions. The Journal of Finance, 44(1), 41-57.

Galbraith, J. K. (1952). American capitalism: The concept of countervailing power. Routledge.

Guiso, L., \& Parigi, G. (1999). Investment and demand uncertainty. Quarterly Journal of Economics 114(1), 185-227.

Hansen, R. G. (1987). A Theory for the Choice of Exchange Medium in Mergers and Acquisitions. The Journal of Business, 60(1), 75-95.

Harford, J., Schonlau, R., \& Stanfield, J. (Forthcoming). Trade relationships, indirect economic links, and mergers. Management Science.

Harroch, R. (2015). 22 Mistakes Made by Sellers in Mergers and Acquisitions. Retrieved October 19, 2018, from https://www.forbes.com/sites/allbusiness/2015/04/29/22-mistakesmade-by-sellers-in-mergers-and-acquisitions/\#3085bcaf28e9.

Hertzel, M. G., Li, Z., Officer, M. S., \& Rodgers, K. J. (2008). Inter-firm linkages and the wealth effects of financial distress along the supply chain. Journal of Financial Economics, 87(2), 374-387.

Huang, H. H., Lobo, G. J., Wang, C., \& Xie, H. (2016). Customer concentration and corporate tax avoidance. Journal of Banking and Finance, 72, 184-200.

Intintoli, V. J., Serfling, M., \& Shaikh, S. (2017). CEO turnovers and disruptions in customersupplier relationships. Journal of Financial and Quantitative Analysis (Vol. 52).

Irvine, P. J., Park, S. S., \& Yildizhan, C. (2016). Customer-base concentration, profitability, and the relationship life cycle. Accounting Review, 91(3), 883-906. 
Kalwani, M. U., \& Narayandas, N. (1995). Long-term manufacturer-supplier relationships: Do they pay off for supplier firms? Journal of Marketing, 59(1), 1-16.

Karampatsas, N., Petmezas, D., \& Travlos, N. G. (2014). Credit ratings and the choice of payment method in mergers and acquisitions. Journal of Corporate Finance, 25, 474-493.

Kinney, M. R., \& Wempe, W. F. (2002). Further evidence on the extent and origins of JIT's profitability effects. The Accounting Review, 77(1), 203-225.

Kohers, N., \& Ang, J. (2000). Earnouts in Mergers: Agreeing to Disagree and Agreeing to Stay. The Journal of Business, 73(3), 445-476.

Kolay, M., Lemmon, M., \& Tashjian, E. (2016). Spreading the misery? Sources of bankruptcy spillover in the supply chain. Journal of Financial and Quantitative Analysis, 51(6), 19551990.

Krishnaswami, S., \& Subramaniam, V. (1999). Information asymmetry, valuation, and the corporate spin-off decision. Journal of Financial Economics, 53(1), 73-112.

Krug, J. A., Hegarty, W. H., Strategic, S., Journal, M., \& Feb, N. (2016). Predicting Who Stays and Leaves after an Acquisition: A Study of Top Managers in Multinational Firms. Strategic Management Journal, 22(2), 185-196.

Loten, A. (2012, June 6). Small Firms’ Big Customers Are Slow to Pay. Wall Street Journal. Retrieved from https://www.wsj.com/articles/SB10001424052702303296604577450561434496668

Marquardt, C., \& Zur, E. (2015). The Role of Accounting Quality in the M\&A Market. Management Science, 61(3), 604-623.

Martin, K. (1996). The Method of Payment in Corporate Acquisitions, Investment Opportunities, and Management Ownership. The Journal of Finance, 51(4), 1227-1246.

Martynova, M., \& Renneboog, L. (2009). What determines the financing decision in corporate takeovers: Cost of capital, agency problems, or the means of payment? Journal of Corporate Finance, 15(3), 290-315.

Nead, N. (2017). Increasing Business Valuations for M\&A: Diversify the Customer Base. Retrieved July 9, 2018, from https://investmentbank.com/increasing-business-valuationsfor-ma-diversify-the-customer-base/

Officer, M. S. (2004). Collars and Renegotiation in Mergers and Acquisitions. The Journal of Finance, 59(6), 2719-2743.

Officer, M. S., Poulsen, A. B., \& Stegemoller, M. (2009). Target-firm information asymmetry and acquirer returns. Review of Finance, 13(3), 467-493. 
Palepu, K. G. (1986). Predicting takeover targets. A methodological and empirical analysis. Journal of Accounting and Economics, 8(1), 3-35.

Patatoukas, P. N. (2012). Customer-base concentration: Implications for firm performance and capital markets. The Accounting Review, 87(2), 363-392.

Perry, J. S., \& Herd, T. J. (2004). Reducing M\&A risk through improved due diligence. Strategy \& Leadership, 32(2), 12-19.

River's Edge. (2014). Deal Killer \#1 = Customer Concentration. Retrieved July 9, 2018, from http://www.riversedgealliance.com/blog/deal-killer-equals-customer-concentration

Sebenius, J. (1992). Negotiation Analysis: A Characterization and Review. Management Science, 38(1), 18-38.

Skaife, H. A., \& Wangerin, D. D. (2013). Target financial reporting quality and M\&A deals that go bust. Contemporary Accounting Research, 30(2), 719-749.

Sutton, C., \& Nelson, B. (2009, April). Forbes 2009. Forbes Magazine. Retrieved from https://www.forbes.com/2009/04/15/biggest-business-risks-entrepreneurs-managementrisk.html\#305d05e9718b

Titman, S., \& Wessels, R. (1998). The Determinants of Capital Structure Choice. The Journal of Finance, 43(1), 1-19.

Uysal, V. B. (2011). Deviation from the target capital structure and acquisition choices. Journal of Financial Economics, 102(3), 602-620.

Wagner, J. (2017). What's your customer concentration? Retrieved July 9, 2018, from http://www.lbmjournal.com/whats-your-customer-concentration/

Xie, Y., Yi, H. S., \& Zhang, Y. (2013). The value of big N target auditors in corporate takeovers. Auditing: A Journal of Practice \& Theory, 32(3), 141-169. 


\section{The appendix}

\section{Variable definitions}

\begin{tabular}{|c|c|c|}
\hline Variable & & Definition \\
\hline \multicolumn{3}{|l|}{ Test Variables } \\
\hline CustomerConcentration & $=$ & one of CustomerHHI, MajorCustomer, and TotalMajorCustomerSales, defined as follows: \\
\hline CustomerHHI & $=$ & $\begin{array}{l}\text { the squared sum of the ratio of major customer sales to total sales. Summed across all major } \\
\text { customers within a firm and decile ranked. }\end{array}$ \\
\hline MajorCustomer & $=$ & one if the firm has a major customer; zero otherwise. \\
\hline TotalMajorCustomerSales & $=$ & the sum of all sales to major customers divided by total sales, decile ranked. \\
\hline Govt_Concentration & $=$ & $\begin{array}{l}\text { one of CustomerHHI, MajorCustomer, and TotalMajorCustomerSales, defined as above, except that only } \\
\text { governmental customers are included in the calculation. }\end{array}$ \\
\hline NonGovt_Concentration & $=$ & $\begin{array}{l}\text { one of CustomerHHI, MajorCustomer, and TotalMajorCustomerSales, defined as above, except that only } \\
\text { non-governmental customers are included in the calculation. }\end{array}$ \\
\hline CustomerConcentration_Long & $=$ & $\begin{array}{l}\text { one of CustomerHHI, MajorCustomer, and TotalMajorCustomerSales, defined as above, except that only } \\
\text { customers that have had a disclosed relationship with the firm for an above median number of } \\
\text { consecutive years are included in the calculation. }\end{array}$ \\
\hline CustomerConcentration_Short & $=$ & $\begin{array}{l}\text { one of CustomerHHI, MajorCustomer, and TotalMajorCustomerSales, defined as above, except that only } \\
\text { customers that have had a disclosed relationship with the firm for a below median number of consecutive } \\
\text { years are included in the calculation. }\end{array}$ \\
\hline
\end{tabular}

\section{Dependent Variables}

BidIndicator

$=\quad$ one for a firm-year if the firm received a bid prior to the disclosure of the subsequent $10-\mathrm{K}$; zero

PercentStock otherwise.

$=\quad$ the percent of payment that was offered in stock.

Control Variables

AbnormalReturn

$=$ market adjusted monthly returns cumulated over the twelve months prior to year-end.

\begin{tabular}{|c|c|c|}
\hline AcquirerMTB & $=$ & acquirer market value of equity divided by acquirer book equity. \\
\hline AcquirerROA & $=$ & acquirer net income divided by acquirer assets. \\
\hline AcquirerSales & $=$ & acquirer sales in billions. \\
\hline CompetedBid & $=$ & one if SDC identifies the bid as a challenged bid; zero otherwise. \\
\hline Growth & $=$ & the average percent change in sales over the previous three years. \\
\hline GrowthMismatch & $=$ & $\begin{array}{l}\text { one if there is a growth-resource mismatch, zero otherwise. There is a growth-resource mismatch if a firm } \\
\text { has high leverage, low liquidity, and high growth or low leverage, high liquidity, and low growth. Low } \\
\text { and high indicate below and above median, respectively. (Dhaliwal et al., 2016) }\end{array}$ \\
\hline InstitutionalOwnership & $=$ & the percent of shares held by institutional investors. \\
\hline Leverage & $=$ & total long-term debt divided by common equity. \\
\hline Liquidity & $=$ & $\begin{array}{l}\text { net liquid assets divided by book assets averaged between periods } t \text { through } \mathrm{t}-3 \text {. Net liquid assets equals } \\
\text { (cash + marketable securities - current liabilities). }\end{array}$ \\
\hline$M T B$ & $=$ & market value of equity divided by book equity. \\
\hline PERatio & $=$ & share price divided by earnings per share. \\
\hline RelativeSize & $=$ & target assets divided by acquirer assets, decile ranked and scaled to between zero and one. \\
\hline$R O E$ & $=$ & net income divided by total stockholder's equity. \\
\hline ReturnVolatility & $=$ & $\begin{array}{l}\text { the standard deviation of daily returns over the twelve months ending five days prior to the bid } \\
\text { announcement date. }\end{array}$ \\
\hline SameIndustry & $=$ & one if the target and acquirer have the same two-digit SIC code; zero otherwise. \\
\hline Size & $=$ & total assets in billions \\
\hline SwitchingCosts & $=$ & $\begin{array}{l}\text { Industry market share, decile ranked and scaled to between zero and one. Industry market share is total } \\
\text { target sales over total target industry sales, using Fama-French } 48 \text { industries. }\end{array}$ \\
\hline
\end{tabular}




\section{Table 1}

Descriptive Statistics

\begin{tabular}{|c|c|c|c|c|c|}
\hline Variable & Mean & Std. & P25 & Median & P75 \\
\hline \multicolumn{6}{|c|}{ Panel A: The bid sample $(N=108,430)$} \\
\hline \multicolumn{6}{|c|}{ Customer Concentration Measures } \\
\hline CustomerHHI & 0.060 & 0.153 & 0.000 & 0.000 & 0.045 \\
\hline MajorCustomer & 0.372 & 0.483 & 0.000 & 0.000 & 1.000 \\
\hline TotalMajorCustomerSales & 0.160 & 0.263 & 0.000 & 0.000 & 0.250 \\
\hline \multicolumn{6}{|c|}{ Dependent Variable and Controls } \\
\hline BidIndicator & 0.078 & 0.268 & 0.000 & 0.000 & 0.000 \\
\hline AbnormalReturn & 0.024 & 0.550 & -0.272 & 0.006 & 0.283 \\
\hline Growth & 0.669 & 26.486 & 0.014 & 0.100 & 0.239 \\
\hline GrowthMismatch & 0.307 & 0.461 & 0.000 & 0.000 & 1.000 \\
\hline InstitutionalOwnership & 0.222 & 0.318 & 0.000 & 0.000 & 0.000 \\
\hline Leverage & 0.596 & 1.814 & 0.001 & 0.220 & 0.715 \\
\hline Liquidity & 0.121 & 0.223 & -0.008 & 0.059 & 0.218 \\
\hline$M T B$ & 2.677 & 4.217 & 1.053 & 1.791 & 3.148 \\
\hline PERatio & 13.740 & 52.612 & -2.082 & 12.166 & 21.517 \\
\hline ROE & -0.048 & 0.822 & -0.056 & 0.077 & 0.152 \\
\hline Size & 3.580 & 20.999 & 0.051 & 0.236 & 1.165 \\
\hline Switching Costs & 0.012 & 0.044 & 0.000 & 0.001 & 0.005 \\
\hline \multicolumn{6}{|c|}{ Panel B: The payment method sample $(N=6,215)$} \\
\hline \multicolumn{6}{|c|}{ Customer Concentration Measures } \\
\hline CustomerHHI & 0.057 & 0.150 & 0.000 & 0.000 & 0.040 \\
\hline MajorCustomer & 0.360 & 0.480 & 0.000 & 0.000 & 1.000 \\
\hline TotalMajorCustomerSales & 0.153 & 0.258 & 0.000 & 0.000 & 0.226 \\
\hline \multicolumn{6}{|c|}{ Dependent Variable and Controls } \\
\hline PercentStock & 26.546 & 41.105 & 0.000 & 0.000 & 60.010 \\
\hline AbnormalReturn & -0.031 & 0.531 & -0.312 & -0.034 & 0.242 \\
\hline CompetedBid & 0.131 & 0.337 & 0.000 & 0.000 & 0.000 \\
\hline Growth & 0.299 & 1.883 & 0.015 & 0.100 & 0.237 \\
\hline GrowthMismatch & 0.322 & 0.467 & 0.000 & 0.000 & 1.000 \\
\hline InstitutionalOwnership & 0.196 & 0.303 & 0.000 & 0.000 & 0.336 \\
\hline Leverage & 0.128 & 0.222 & -0.006 & 0.058 & 0.229 \\
\hline Liquidity & 0.678 & 1.894 & 0.001 & 0.222 & 0.809 \\
\hline$M T B$ & 2.350 & 3.572 & 1.019 & 1.625 & 2.668 \\
\hline PERatio & 11.980 & 53.602 & -2.225 & 11.298 & 20.576 \\
\hline$R O E$ & -0.063 & 0.794 & -0.063 & 0.069 & 0.138 \\
\hline ReturnVolatility & 0.039 & 0.025 & 0.023 & 0.032 & 0.047 \\
\hline SameIndustry & 0.470 & 0.499 & 0.000 & 0.000 & 1.000 \\
\hline Size & 1.215 & 4.214 & 0.063 & 0.196 & 0.728 \\
\hline Switching Costs & 0.006 & 0.025 & 0.000 & 0.001 & 0.003 \\
\hline
\end{tabular}

This table presents descriptive statistics for variables used in our analyses. Panel A includes the variables and sample used for bid probability tests. Panel B includes the variables and sample used for payment method tests. See the appendix for all variable definitions. CustomerHHI and TotalMajorCustomerSales, while decile-ranked in all further analyses, are presented in their raw form in this table for descriptive purposes. 
Table 2

Correlations

Panel A: The bid sample $(N=108,430)$

CustomerHHI

MajorCustomer

TotalMajorCustomerSales

BidIndicator

AbnormalReturn

Growth

GrowthMismatch

InstitutionalOwnership

Leverage

Liquidity

MTB

PERatio

$R O E$

Size

15 Switching Costs

$\begin{array}{ccccccccccccccc}(1) & (2) & (3) & (4) & (5) & (6) & (7) & (8) & (9) & (10) & (11) & (12) & (13) & (14) & (15) \\ & & & & & & & & & & & & & & \\ 1.00 & \mathbf{0 . 5 1} & \mathbf{0 . 8 3} & \mathbf{- 0 . 0 1} & 0.00 & 0.00 & \mathbf{- 0 . 0 1} & \mathbf{- 0 . 0 1} & \mathbf{- 0 . 0 4} & \mathbf{0 . 1 2} & \mathbf{0 . 0 2} & \mathbf{- 0 . 0 3} & \mathbf{- 0 . 0 5} & \mathbf{- 0 . 0 5} & \mathbf{- 0 . 0 5} \\ \mathbf{0 . 9 7} & 1.00 & \mathbf{0 . 7 9} & \mathbf{- 0 . 0 1} & \mathbf{0 . 0 1} & 0.00 & 0.00 & \mathbf{0 . 0 1} & \mathbf{- 0 . 0 5} & \mathbf{0 . 0 8} & \mathbf{- 0 . 0 1} & \mathbf{- 0 . 0 2} & \mathbf{- 0 . 0 5} & \mathbf{- 0 . 0 9} & \mathbf{- 0 . 0 6} \\ \mathbf{1 . 0 0} & \mathbf{0 . 9 7} & 1.00 & \mathbf{- 0 . 0 1} & \mathbf{0 . 0 1} & 0.00 & 0.00 & \mathbf{0 . 0 1} & \mathbf{- 0 . 0 5} & \mathbf{0 . 1 3} & \mathbf{0 . 0 1} & \mathbf{- 0 . 0 3} & \mathbf{- 0 . 0 6} & \mathbf{- 0 . 0 8} & \mathbf{- 0 . 0 6} \\ \mathbf{- 0 . 0 1} & \mathbf{- 0 . 0 1} & \mathbf{- 0 . 0 1} & 1.00 & \mathbf{- 0 . 0 3} & 0.00 & \mathbf{0 . 0 1} & \mathbf{- 0 . 0 3} & \mathbf{0 . 0 2} & \mathbf{- 0 . 0 1} & \mathbf{- 0 . 0 2} & \mathbf{- 0 . 0 1} & \mathbf{- 0 . 0 1} & \mathbf{- 0 . 0 3} & \mathbf{- 0 . 0 3} \\ \mathbf{- 0 . 0 1} & \mathbf{- 0 . 0 1} & \mathbf{- 0 . 0 1} & \mathbf{- 0 . 0 3} & 1.00 & \mathbf{- 0 . 0 1} & \mathbf{- 0 . 0 1} & \mathbf{0 . 0 7} & \mathbf{- 0 . 0 2} & \mathbf{0 . 0 5} & \mathbf{0 . 2 0} & \mathbf{0 . 0 6} & \mathbf{0 . 1 0} & 0.00 & 0.00 \\ \mathbf{0 . 0 6} & \mathbf{0 . 0 5} & \mathbf{0 . 0 6} & 0.00 & \mathbf{0 . 0 3} & 1.00 & \mathbf{- 0 . 0 1} & \mathbf{- 0 . 0 1} & 0.00 & 0.00 & \mathbf{0 . 0 2} & 0.00 & 0.00 & 0.00 & 0.00 \\ 0.00 & 0.00 & 0.00 & \mathbf{0 . 0 1} & \mathbf{- 0 . 0 1} & \mathbf{- 0 . 1 1} & 1.00 & \mathbf{- 0 . 0 4} & \mathbf{- 0 . 0 1} & \mathbf{0 . 0 1} & \mathbf{- 0 . 0 7} & \mathbf{- 0 . 0 1} & \mathbf{- 0 . 0 1} & \mathbf{- 0 . 0 3} & \mathbf{- 0 . 0 2} \\ \mathbf{0 . 0 2} & \mathbf{0 . 0 2} & \mathbf{0 . 0 2} & \mathbf{- 0 . 0 4} & \mathbf{0 . 0 8} & \mathbf{0 . 0 1} & \mathbf{- 0 . 0 2} & 1.00 & \mathbf{- 0 . 0 1} & \mathbf{0 . 1 2} & \mathbf{0 . 0 7} & \mathbf{0 . 0 4} & \mathbf{0 . 0 7} & \mathbf{0 . 0 3} & \mathbf{0 . 0 9} \\ \mathbf{- 0 . 1 2} & \mathbf{- 0 . 1 1} & \mathbf{- 0 . 1 2} & \mathbf{0 . 0 2} & \mathbf{- 0 . 0 1} & \mathbf{- 0 . 0 1} & \mathbf{- 0 . 0 4} & \mathbf{- 0 . 0 2} & 1.00 & \mathbf{- 0 . 1 5} & \mathbf{0 . 4 3} & \mathbf{- 0 . 0 1} & \mathbf{- 0 . 1 8} & \mathbf{0 . 0 4} & \mathbf{0 . 0 5} \\ \mathbf{0 . 0 9} & \mathbf{0 . 0 7} & \mathbf{0 . 0 9} & \mathbf{- 0 . 0 1} & \mathbf{0 . 0 4} & \mathbf{0 . 1 3} & \mathbf{- 0 . 0 1} & \mathbf{0 . 1 4} & \mathbf{- 0 . 4 2} & 1.00 & \mathbf{0 . 1 5} & \mathbf{- 0 . 0 2} & \mathbf{- 0 . 0 8} & \mathbf{- 0 . 0 7} & \mathbf{- 0 . 1 0} \\ \mathbf{- 0 . 0 2} & \mathbf{- 0 . 0 2} & \mathbf{- 0 . 0 2} & \mathbf{- 0 . 0 4} & \mathbf{0 . 3 2} & \mathbf{0 . 2 3} & \mathbf{- 0 . 0 7} & \mathbf{0 . 1 5} & \mathbf{0 . 1 1} & \mathbf{0 . 2 2} & 1.00 & \mathbf{0 . 0 3} & \mathbf{- 0 . 2 0} & 0.00 & \mathbf{0 . 0 3} \\ \mathbf{- 0 . 0 8} & \mathbf{- 0 . 0 7} & \mathbf{- 0 . 0 8} & \mathbf{- 0 . 0 2} & \mathbf{0 . 1 9} & \mathbf{0 . 0 7} & \mathbf{- 0 . 0 1} & \mathbf{0 . 1 1} & \mathbf{0 . 0 3} & \mathbf{- 0 . 0 1} & \mathbf{0 . 2 3} & 1.00 & \mathbf{0 . 0 7} & \mathbf{0 . 0 1} & \mathbf{0 . 0 2} \\ \mathbf{- 0 . 0 9} & \mathbf{- 0 . 0 8} & \mathbf{- 0 . 0 9} & \mathbf{- 0 . 0 2} & \mathbf{0 . 2 2} & \mathbf{0 . 1 0} & \mathbf{- 0 . 0 4} & \mathbf{0 . 1 0} & \mathbf{0 . 0 1} & \mathbf{- 0 . 0 9} & \mathbf{0 . 2 1} & \mathbf{0 . 4 0} & 1.00 & \mathbf{0 . 0 4} & \mathbf{0 . 0 6} \\ \mathbf{- 0 . 2 5} & \mathbf{- 0 . 2 4} & \mathbf{- 0 . 2 5} & \mathbf{- 0 . 0 1} & \mathbf{0 . 0 7} & \mathbf{- 0 . 0 4} & \mathbf{- 0 . 0 4} & \mathbf{0 . 2 7} & \mathbf{0 . 3 3} & \mathbf{- 0 . 1 1} & \mathbf{0 . 1 0} & \mathbf{0 . 2 4} & \mathbf{0 . 2 9} & 1.00 & \mathbf{0 . 3 5} \\ \mathbf{- 0 . 1 7} & \mathbf{- 0 . 1 5} & \mathbf{- 0 . 1 7} & \mathbf{- 0 . 0 1} & \mathbf{0 . 0 5} & \mathbf{- 0 . 0 6} & \mathbf{- 0 . 0 5} & \mathbf{0 . 1 8} & \mathbf{0 . 2 8} & \mathbf{- 0 . 1 9} & \mathbf{0 . 0 8} & \mathbf{0 . 2 5} & \mathbf{0 . 3 2} & \mathbf{0 . 7 2} & 1.00\end{array}$


Table 2, Cont.

\section{Correlations}

Panel B: The payment method sample $(N=6,215)$

\begin{tabular}{|c|c|c|c|c|c|c|c|c|c|c|c|c|c|c|c|c|c|c|c|}
\hline & & (1) & (2) & (3) & (4) & (5) & (6) & (7) & (8) & (9) & (10) & (11) & (12) & (13) & (14) & (15) & (16) & (17) & (18) \\
\hline 1 & CustomerHHI & 1.00 & 0.51 & 0.83 & 0.00 & -0.01 & -0.05 & 0.04 & -0.02 & $\mathbf{0 . 0 3}$ & -0.01 & 0.11 & 0.02 & -0.01 & -0.01 & 0.06 & -0.02 & -0.07 & -0.02 \\
\hline 2 & MajorCustomer & 0.97 & 1.00 & 0.79 & -0.01 & -0.04 & -0.05 & 0.01 & -0.01 & 0.03 & -0.04 & 0.09 & -0.01 & -0.01 & -0.03 & 0.13 & -0.04 & -0.10 & -0.02 \\
\hline 3 & TotalMajorCustomerSales & 1.00 & 0.97 & 1.00 & 0.00 & -0.02 & -0.06 & 0.03 & -0.01 & 0.05 & -0.03 & 0.13 & 0.01 & -0.01 & -0.03 & 0.11 & -0.02 & -0.09 & -0.03 \\
\hline 4 & PercentStock & -0.01 & -0.02 & -0.01 & 1.00 & 0.05 & -0.12 & 0.03 & -0.05 & -0.05 & 0.00 & 0.02 & 0.10 & 0.02 & -0.01 & 0.02 & 0.26 & 0.11 & 0.00 \\
\hline 5 & AbnormalReturn & -0.05 & -0.05 & -0.05 & 0.06 & 1.00 & 0.02 & -0.02 & 0.03 & 0.05 & 0.02 & 0.01 & 0.21 & 0.02 & 0.15 & -0.19 & 0.04 & 0.03 & 0.01 \\
\hline 6 & CompetedBid & -0.06 & -0.05 & -0.06 & -0.11 & 0.03 & 1.00 & 0.01 & 0.02 & -0.04 & -0.01 & -0.06 & -0.04 & -0.02 & 0.05 & -0.07 & -0.03 & 0.06 & 0.05 \\
\hline 7 & Growth & 0.06 & 0.05 & 0.06 & 0.13 & -0.01 & -0.08 & 1.00 & -0.05 & 0.01 & 0.00 & 0.09 & 0.03 & -0.02 & -0.06 & 0.05 & 0.01 & -0.02 & -0.02 \\
\hline 8 & GrowthMismatch & -0.01 & -0.01 & -0.01 & -0.05 & $\mathbf{0 . 0 3}$ & 0.02 & -0.12 & 1.00 & -0.04 & -0.01 & 0.02 & -0.06 & .02 & $\mathbf{0 . 0 3}$ & -0.03 & -0.03 & -0.03 & -0.03 \\
\hline 9 & InstitutionalOwnership & 0.05 & 0.05 & 0.05 & 0.00 & 0.04 & -0.07 & 0.02 & -0.02 & 1.00 & -0.01 & 0.20 & 0.10 & .01 & 0.03 & -0.14 & 0.07 & 0.10 & 0.03 \\
\hline 10 & Lever & -0.11 & -0.11 & -0.11 & 0.03 & 0.04 & 0.04 & 0.01 & -0.06 & -0.07 & 1.00 & -0.16 & 0.46 & 0.00 & -0.11 & -0.04 & 0.01 & 0.06 & 0.03 \\
\hline 11 & Liquidity & 0.09 & 0.08 & 0.09 & 0.01 & 0.00 & -0.05 & 0.13 & 0.00 & 0.20 & -0.45 & 1.00 & 0.14 & -0.04 & -0.12 & 0.07 & 0.07 & -0.09 & -0.10 \\
\hline 12 & $M T B$ & -0.01 & -0.02 & -0.02 & 0.15 & 0.31 & -0.06 & 0.25 & -0.07 & 0.12 & 0.15 & 0.20 & 1.00 & 0.00 & -0.11 & -0.05 & 0.06 & 0.03 & 0.02 \\
\hline 13 & PERatio & -0.04 & -0.04 & -0.04 & 0.05 & 0.18 & 0.00 & 0.07 & 0.01 & 0.02 & 0.03 & -0.03 & 0.21 & 1.00 & 0.07 & -0.11 & -0.02 & 0.01 & 0.00 \\
\hline 14 & $R O E$ & -0.05 & -0.05 & -0.05 & $\mathbf{0 . 0 3}$ & 0.25 & 0.04 & 0.09 & -0.01 & -0.02 & 0.07 & -0.13 & 0.21 & 0.40 & 1.00 & -0.28 & 0.00 & 0.06 & 0.05 \\
\hline 15 & ReturnVolatility & 0.17 & 0.17 & 0.17 & 0.01 & -0.21 & -0.07 & 0.11 & -0.03 & -0.06 & -0.18 & 0.10 & -0.17 & -0.33 & -0.37 & 1.00 & -0.04 & -0.16 & -0.10 \\
\hline 16 & SameIndustry & -0.03 & -0.04 & -0.03 & 0.27 & 0.05 & -0.03 & 0.06 & -0.03 & 0.08 & 0.01 & 0.05 & 0.09 & 0.00 & 0.01 & -0.04 & 1.00 & 0.07 & -0.02 \\
\hline 17 & Size & -0.19 & -0.19 & -0.19 & 0.11 & 0.08 & 0.08 & -0.02 & -0.03 & 0.11 & 0.34 & -0.16 & 0.10 & 0.19 & 0.25 & -0.51 & 0.10 & 1.00 & 0.35 \\
\hline 18 & SwitchingCosts & -0.06 & -0.05 & -0.06 & -0.02 & 0.02 & 0.10 & -0.03 & -0.04 & 0.01 & 0.24 & -0.21 & 0.06 & 0.15 & 0.25 & -0.25 & -0.06 & 0.58 & 1.00 \\
\hline
\end{tabular}

This table presents correlations among the variables used in our analyses. Pearson (Spearman) correlations appear above (below) the diagonal. Panel A includes the variables and sample used for bid probability tests. Panel B includes the variables and sample used for payment method tests. See the appendix for all variable definitions. Bold indicates significance at the 10 percent level. 
Table 3

Customer concentration and bid likelihood

\begin{tabular}{|c|c|c|c|c|c|c|}
\hline \multirow[t]{2}{*}{$\begin{array}{l}\text { Dependent variable }=\text { BidIndicator } \\
\qquad \text { Customer Concentration = }\end{array}$} & \multicolumn{2}{|c|}{$\begin{array}{c}(1) \\
\text { Major } \\
\text { Customer } \\
\end{array}$} & \multicolumn{2}{|c|}{$\begin{array}{l}(2) \\
\text { Customer } \\
\text { HHI } \\
\end{array}$} & \multicolumn{2}{|c|}{$\begin{array}{c}(3) \\
\text { Total Major } \\
\text { Customer Sales } \\
\end{array}$} \\
\hline & $\begin{array}{r}-2.618 \\
-(69.83)\end{array}$ & $* * *$ & $\begin{array}{r}-2.553 \\
-(53.83)\end{array}$ & $* * *$ & $\begin{array}{r}-2.561 \\
-(53.91)\end{array}$ & $* * *$ \\
\hline CustomerConcentration & $\begin{array}{l}-0.104 \\
-(3.27)\end{array}$ & $* * *$ & $\begin{array}{l}-0.022 \\
-(3.37)\end{array}$ & $* * *$ & $\begin{array}{l}-0.020 \\
-(3.11)\end{array}$ & $* * *$ \\
\hline AbnormalReturn & $\begin{array}{l}-0.122 \\
-(4.82)\end{array}$ & $* * *$ & $\begin{array}{l}-0.122 \\
-(4.82)\end{array}$ & $* * *$ & $\begin{array}{l}-0.122 \\
-(4.82)\end{array}$ & $* * *$ \\
\hline$R O E$ & $\begin{array}{l}-0.020 \\
-(1.12)\end{array}$ & & $\begin{array}{l}-0.020 \\
-(1.12)\end{array}$ & & $\begin{array}{l}-0.020 \\
-(1.11)\end{array}$ & \\
\hline GrowthMismatch & $\begin{array}{l}0.008 \\
(0.27)\end{array}$ & & $\begin{array}{l}0.008 \\
(0.27)\end{array}$ & & $\begin{array}{l}0.008 \\
(0.27)\end{array}$ & \\
\hline Growth & $\begin{array}{l}-0.007 \\
-(1.65)\end{array}$ & $*$ & $\begin{array}{l}-0.007 \\
-(1.65)\end{array}$ & $*$ & $\begin{array}{l}-0.007 \\
-(1.65)\end{array}$ & $*$ \\
\hline Liquidity & $\begin{array}{l}0.077 \\
(1.12)\end{array}$ & & $\begin{array}{l}0.080 \\
(1.17)\end{array}$ & & $\begin{array}{l}0.080 \\
(1.16)\end{array}$ & \\
\hline Leverage & $\begin{array}{l}0.060 \\
(7.42)\end{array}$ & $* * *$ & $\begin{array}{l}0.060 \\
(7.42)\end{array}$ & $* * *$ & $\begin{array}{l}0.060 \\
(7.43)\end{array}$ & $* * *$ \\
\hline Size & $\begin{array}{l}-0.013 \\
-(4.35)\end{array}$ & $* * *$ & $\begin{array}{l}-0.013 \\
-(4.35)\end{array}$ & $* * *$ & $\begin{array}{l}-0.013 \\
-(4.34)\end{array}$ & $* * *$ \\
\hline$M T B$ & $\begin{array}{l}-0.033 \\
-(7.60)\end{array}$ & $* * *$ & $\begin{array}{l}-0.033 \\
-(7.60)\end{array}$ & $* * *$ & $\begin{array}{l}-0.033 \\
-(7.60)\end{array}$ & $* * *$ \\
\hline PERatio & $\begin{array}{l}-0.001 \\
-(2.97)\end{array}$ & $* * *$ & $\begin{array}{l}-0.001 \\
-(2.98)\end{array}$ & $* * *$ & $\begin{array}{l}-0.001 \\
-(2.98)\end{array}$ & $* * *$ \\
\hline InstitutionalOwnership & $\begin{array}{l}-0.047 \\
-(0.91)\end{array}$ & & $\begin{array}{l}-0.048 \\
-(0.93)\end{array}$ & & $\begin{array}{l}-0.047 \\
-(0.92)\end{array}$ & \\
\hline $\begin{array}{l}\text { Industry and Year Fixed Effects } \\
\text { Pseudo } \mathrm{R}^{2} \\
\text { Observations }\end{array}$ & $\begin{array}{r}\mathrm{Y} \\
0.043 \\
108,430 \\
\end{array}$ & & $\begin{array}{r}\mathrm{Y} \\
0.043 \\
108,430 \\
\end{array}$ & & $\begin{array}{r}\mathrm{Y} \\
0.043 \\
108,430 \\
\end{array}$ & \\
\hline
\end{tabular}

This table reports results from Logit regressions relating the probability of receiving a bid to customer concentration measures and controls for Compustat firms from 1985-2016. The dependent variable is BidIndicator. See the appendix for all variable definitions. Industry fixed effects are defined at the Fama-French 48 level. Continuous variables are winsorized at 1 and 99. T-statistics (reported in parentheses) are based on standard errors clustered at the firm level. *,**, and *** denote significance at the 10 percent, 5 percent, and 1 percent level, respectively. 


\section{Table 4}

Customer concentration and payment method

Panel A: The full payment method sample

\begin{tabular}{|c|c|c|c|c|c|c|}
\hline \multirow{2}{*}{$\begin{array}{l}\text { Dependent variable }=\text { Percent } \text { Stock } \\
\qquad \text { Customer Concentration = } \\
\text { Intercept }\end{array}$} & \multicolumn{2}{|c|}{$\begin{array}{c}(1) \\
\text { Major } \\
\text { Customer }\end{array}$} & \multicolumn{2}{|c|}{$\begin{array}{l}(2) \\
\text { Customer } \\
\text { HHI }\end{array}$} & \multicolumn{2}{|c|}{$\begin{array}{c}(3) \\
\text { Total Major } \\
\text { Customer Sales }\end{array}$} \\
\hline & $\begin{array}{r}25.998 \\
(7.70)\end{array}$ & $* * *$ & $\begin{array}{r}24.061 \\
(7.17)\end{array}$ & $* * *$ & $\begin{array}{r}24.006 \\
(7.16)\end{array}$ & $* * *$ \\
\hline CustomerConcentration & $\begin{array}{l}3.246 \\
(2.92)\end{array}$ & $* * *$ & $\begin{array}{l}0.617 \\
(2.73)\end{array}$ & $* * *$ & $\begin{array}{l}0.666 \\
(2.96)\end{array}$ & $* * *$ \\
\hline AbnormalReturn & $\begin{array}{l}2.922 \\
(2.85)\end{array}$ & $* * *$ & $\begin{array}{l}2.904 \\
(2.83)\end{array}$ & $* * *$ & $\begin{array}{l}2.913 \\
(2.84)\end{array}$ & $* * *$ \\
\hline$R O E$ & $\begin{array}{l}-0.596 \\
-(0.89)\end{array}$ & & $\begin{array}{l}-0.602 \\
-(0.90)\end{array}$ & & $\begin{array}{l}-0.603 \\
-(0.90)\end{array}$ & \\
\hline GrowthMismatch & $\begin{array}{l}-3.860 \\
-(3.88)\end{array}$ & $* * *$ & $\begin{array}{l}-3.861 \\
-(3.88)\end{array}$ & $* * *$ & $\begin{array}{l}-3.855 \\
-(3.88)\end{array}$ & $* * *$ \\
\hline Growth & $\begin{array}{l}0.350 \\
(1.64)\end{array}$ & & $\begin{array}{l}0.346 \\
(1.62)\end{array}$ & & $\begin{array}{l}0.346 \\
(1.63)\end{array}$ & \\
\hline Liquidity & $\begin{array}{l}7.744 \\
(2.86)\end{array}$ & $* * *$ & $\begin{array}{l}7.624 \\
(2.82)\end{array}$ & $* * *$ & $\begin{array}{l}7.627 \\
(2.82)\end{array}$ & $* * *$ \\
\hline Leverage & $\begin{array}{l}-1.305 \\
-(4.71)\end{array}$ & $* * *$ & $\begin{array}{l}-1.308 \\
-(4.72)\end{array}$ & $* * *$ & $\begin{array}{l}-1.308 \\
-(4.72)\end{array}$ & $* * *$ \\
\hline Size & $\begin{array}{l}1.131 \\
(8.30)\end{array}$ & $* * *$ & $\begin{array}{l}1.131 \\
(8.29)\end{array}$ & $* * *$ & $\begin{array}{l}1.132 \\
(8.30)\end{array}$ & $* * *$ \\
\hline$M T B$ & $\begin{array}{l}1.080 \\
(6.33)\end{array}$ & $* * *$ & $\begin{array}{l}1.081 \\
(6.33)\end{array}$ & $* * *$ & $\begin{array}{l}1.081 \\
(6.33)\end{array}$ & $* * *$ \\
\hline PERatio & $\begin{array}{l}0.012 \\
(1.30)\end{array}$ & & $\begin{array}{l}0.012 \\
(1.30)\end{array}$ & & $\begin{array}{l}0.012 \\
(1.30)\end{array}$ & \\
\hline InstitutionalOwnership & $\begin{array}{l}-0.739 \\
-(0.45)\end{array}$ & & $\begin{array}{l}-0.733 \\
-(0.44)\end{array}$ & & $\begin{array}{l}-0.745 \\
-(0.45)\end{array}$ & \\
\hline Same Industry & $\begin{array}{l}14.014 \\
(13.89)\end{array}$ & $* * *$ & $\begin{array}{r}14.017 \\
(13.89)\end{array}$ & $* * *$ & $\begin{array}{r}14.021 \\
(13.90)\end{array}$ & $* * *$ \\
\hline Return Volatility & $\begin{array}{r}21.675 \\
(0.87)\end{array}$ & & $\begin{array}{r}21.676 \\
(0.87)\end{array}$ & & $\begin{array}{r}21.409 \\
(0.86)\end{array}$ & \\
\hline Competed Bid & $\begin{array}{l}-8.872 \\
-(7.23)\end{array}$ & $* * *$ & $\begin{array}{l}-8.843 \\
-(7.20)\end{array}$ & $* * *$ & $\begin{array}{l}-8.845 \\
-(7.20)\end{array}$ & $* * *$ \\
\hline $\begin{array}{l}\text { Industry and Year Fixed Effects } \\
\text { Adjusted } \mathrm{R}^{2} \\
\text { Observations }\end{array}$ & $\begin{array}{r}Y \\
0.241 \\
6,215 \\
\end{array}$ & & $\begin{array}{r}\mathrm{Y} \\
0.241 \\
6,215 \\
\end{array}$ & & $\begin{array}{r}Y \\
0.241 \\
6,215 \\
\end{array}$ & \\
\hline $\begin{array}{l}\text { This table reports results from OLS regressions relating the payr } \\
\text { from 1985-2016. The dependent variable is Percent Stock. See t } \\
\text { the Fama-French } 48 \text { level. Continuous variables are winsorized } \\
\text { clustered at the firm level. *, **, and } * * * \text { denote significance at }\end{array}$ & percent, 5 & $\begin{array}{l}\text { custo } \\
\text { all va } \\
\text { tatisti } \\
5 \text { perc }\end{array}$ & $\begin{array}{l}\text { ration meas } \\
\text { tions. Indu } \\
\text { in parenthe } \\
\text { ercent leve }\end{array}$ & $\begin{array}{l}\text { asures } \\
\text { ustry } \\
\text { eses) }\end{array}$ & $\begin{array}{l}\text { trols for bid of } \\
\text { ects are define } \\
\text { on standard } \\
\end{array}$ & $\begin{array}{l}\text { ffers } \\
\text { d at } \\
\text { errors }\end{array}$ \\
\hline
\end{tabular}


Table 4, cont.

Customer concentration and payment method

Panel B: The public acquirer sample

\begin{tabular}{|c|c|c|c|c|c|c|}
\hline \multirow{2}{*}{$\begin{array}{l}\text { Dependent variable }=\text { Percent } \text { Stock } \\
\qquad \text { Customer Concentration = } \\
\text { Customer concentration variables }\end{array}$} & \multicolumn{2}{|c|}{$\begin{array}{c}(1) \\
\text { Major } \\
\text { Customer }\end{array}$} & \multicolumn{2}{|c|}{$\begin{array}{c}(2) \\
\text { Customer } \\
\text { HHI }\end{array}$} & \multicolumn{2}{|c|}{$\begin{array}{c}(3) \\
\text { Total Major } \\
\text { Customer Sales } \\
\end{array}$} \\
\hline & & & & & & \\
\hline CustomerConcentration $\left(\gamma_{1}\right)$ & $\begin{array}{r}-3.249 \\
-(1.02)\end{array}$ & & $\begin{array}{l}-0.594 \\
-(0.95)\end{array}$ & & $\begin{array}{l}-0.538 \\
-(0.86)\end{array}$ & \\
\hline CustomerConcentration $*$ RelativeSize $\left(\gamma_{2}\right)$ & $\begin{array}{r}10.831 \\
(1.99)\end{array}$ & $* *$ & $\begin{array}{r}2.118 \\
(1.98)\end{array}$ & $* *$ & $\begin{array}{r}2.188 \\
(2.04)\end{array}$ & $* *$ \\
\hline \multicolumn{7}{|l|}{ Acquirer controls } \\
\hline AcquirerSales & $\begin{array}{l}-0.100 \\
-(2.34)\end{array}$ & $* *$ & $\begin{array}{l}-0.099 \\
-(2.32)\end{array}$ & $* *$ & $\begin{array}{l}-0.099 \\
-(2.32)\end{array}$ & $* *$ \\
\hline AcquirerROA & $\begin{array}{r}-20.749 \\
-(2.96)\end{array}$ & $* * *$ & $\begin{array}{r}-20.639 \\
-(2.93)\end{array}$ & $* * *$ & $\begin{array}{r}-20.673 \\
-(2.95)\end{array}$ & $* * *$ \\
\hline AcquirerMTB & $\begin{array}{r}0.003 \\
(0.36)\end{array}$ & & $\begin{array}{r}0.003 \\
(0.35)\end{array}$ & & $\begin{array}{r}0.003 \\
(0.36)\end{array}$ & \\
\hline RelativeSize & $\begin{array}{r}25.834 \\
(7.05)\end{array}$ & $* * *$ & $\begin{array}{r}19.669 \\
(3.29)\end{array}$ & $* * *$ & $\begin{array}{r}19.334 \\
(3.24)\end{array}$ & $* * *$ \\
\hline \multicolumn{7}{|l|}{ Target controls } \\
\hline $\begin{array}{l}\text { AbnormalReturn } \\
\text { ROE } \\
\text { GrowthMismatch } \\
\text { Growth } \\
\text { Liquidity } \\
\text { Leverage } \\
\text { Size } \\
\text { MTB } \\
\text { PERatio } \\
\text { InstitutionalOwnership } \\
\text { Same Industry } \\
\text { Return Volatility } \\
\text { Competed Bid }\end{array}$ & $\begin{array}{r}2.229 \\
-0.769 \\
-4.893 \\
-0.195 \\
8.338 \\
-1.731 \\
0.968 \\
1.164 \\
0.022 \\
-3.439 \\
2.153 \\
46.043 \\
-13.746\end{array}$ & $\begin{array}{l}* * * \\
* \\
* * * \\
* * * \\
* * *\end{array}$ & $\begin{array}{r}2.231 \\
-0.759 \\
-4.890 \\
-0.197 \\
8.237 \\
-1.727 \\
0.969 \\
1.159 \\
0.022 \\
-3.429 \\
2.193 \\
46.469 \\
-13.742\end{array}$ & $\begin{array}{l}\text { *** } \\
* \\
* * * \\
* * * \\
* * *\end{array}$ & $\begin{array}{r}2.251 \\
-0.768 \\
-4.865 \\
-0.197 \\
8.161 \\
-1.729 \\
0.970 \\
1.161 \\
0.022 \\
-3.430 \\
2.212 \\
45.651 \\
-13.731\end{array}$ & $\begin{array}{l}* * * \\
* \\
* * * \\
* * * \\
* * * \\
\\
* * *\end{array}$ \\
\hline $\begin{array}{l}\text { Industry and Year Fixed Effects } \\
\text { Adjusted } \mathrm{R}^{2} \\
\text { Observations }\end{array}$ & $\begin{array}{r}\mathrm{Y} \\
0.275 \\
2,310 \\
\end{array}$ & . & $\begin{array}{r}\mathrm{Y} \\
0.275 \\
2,310 \\
\end{array}$ & & $\begin{array}{r}\mathrm{Y} \\
0.275 \\
2,310 \\
\end{array}$ & \\
\hline $\begin{array}{l}\text { Total effect of cust. concentration }\left(\gamma_{1}+\gamma_{2}\right) \\
\text { t-test of }\left(\gamma_{1}+\gamma_{2}\right)=0 \text { : }\end{array}$ & $\begin{array}{l}7.582 \\
(2.13) \\
\end{array}$ & $* *$ & $\begin{array}{l}1.524 \\
(2.13)\end{array}$ & & $\begin{array}{l}1.650 \\
(2.32) \\
\end{array}$ & \\
\hline $\begin{array}{l}\text { This table reports results from OLS regressions relating the payr } \\
\text { from 1985-2016. The dependent variable is Percent Stock. See t } \\
\text { the Fama-French } 48 \text { level. Continuous variables are winsorized } \\
\text { clustered at the firm level. *, **, and } * * * \text { denote significance at } \\
\text { intercepts and t-stats for target controls have been repressed. }\end{array}$ & $\begin{array}{l}\text { method to } \\
\text { ppendix for } \\
\text { and } 99 . \text { T-st } \\
10 \text { percent, } 5\end{array}$ & $\begin{array}{l}\text { cust } \\
\text { r all } \\
5 \text { pe }\end{array}$ & $\begin{array}{l}\text { tration meas } \\
\text { itions. Indu } \\
\text { in parenthe } \\
\text { percent leve }\end{array}$ & $\begin{array}{l}\text { asure } \\
\text { ustry } \\
\text { neses } \\
\text { el, re }\end{array}$ & $\begin{array}{l}\text { trols for bid o } \\
\text { ects are define } \\
\text { d on standard } \\
\text { y. For brevity, }\end{array}$ & $\begin{array}{l}\text { ffers } \\
\text { ed at } \\
\text { errors }\end{array}$ \\
\hline
\end{tabular}




\section{Table 5}

Government and non-government customer concentration

\section{Panel A: Bid likelihood}

\begin{tabular}{|c|c|c|c|c|c|c|}
\hline 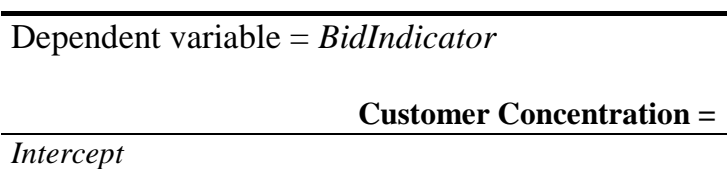 & \multicolumn{2}{|c|}{$\begin{array}{c}(1) \\
\text { Major } \\
\text { Customer }\end{array}$} & \multicolumn{2}{|c|}{$\begin{array}{l}(2) \\
\text { Customer } \\
\text { HHI }\end{array}$} & \multicolumn{2}{|c|}{$\begin{array}{c}(3) \\
\text { Total Major } \\
\text { Customer Sales }\end{array}$} \\
\hline & $\begin{array}{r}-2.618 \\
-(69.88)\end{array}$ & $* * *$ & $\begin{array}{r}-2.537 \\
-(33.64)\end{array}$ & *** & $\begin{array}{r}-2.543 \\
-(33.67)\end{array}$ & $* * *$ \\
\hline NonGovt_Concentration $\left(\eta_{1}\right)$ & $\begin{array}{l}-0.122 \\
-(3.68)\end{array}$ & $* * *$ & $\begin{array}{l}-0.026 \\
-(3.91)\end{array}$ & $* * *$ & $\begin{array}{r}-0.025 \\
-(3.76)\end{array}$ & $* * *$ \\
\hline Govt_Concentration $\left(\eta_{2}\right)$ & $\begin{array}{l}-0.003 \\
-(0.05)\end{array}$ & & $\begin{array}{l}-0.001 \\
-(0.06)\end{array}$ & & $\begin{array}{r}0.000 \\
-(0.03)\end{array}$ & \\
\hline AbnormalReturn & $\begin{array}{l}-0.122 \\
-(4.81)\end{array}$ & $* * *$ & $\begin{array}{r}-0.122 \\
-(4.81)\end{array}$ & $* * *$ & $\begin{array}{r}-0.122 \\
-(4.81)\end{array}$ & $* * *$ \\
\hline$R O E$ & $\begin{array}{l}-0.021 \\
-(1.15)\end{array}$ & & $\begin{array}{l}-0.021 \\
-(1.17)\end{array}$ & & $\begin{array}{l}-0.021 \\
-(1.16)\end{array}$ & \\
\hline GrowthMismatch & $\begin{array}{l}0.007 \\
(0.25)\end{array}$ & & $\begin{array}{l}0.007 \\
(0.24)\end{array}$ & & $\begin{array}{l}0.007 \\
(0.24)\end{array}$ & \\
\hline Growth & $\begin{array}{l}-0.007 \\
-(1.66)\end{array}$ & $*$ & $\begin{array}{l}-0.007 \\
-(1.65)\end{array}$ & $*$ & $\begin{array}{l}-0.007 \\
-(1.65)\end{array}$ & $*$ \\
\hline Liquidity & $\begin{array}{l}0.084 \\
(1.22)\end{array}$ & & $\begin{array}{l}0.088 \\
(1.28)\end{array}$ & & $\begin{array}{c}0.088 \\
(1.28)\end{array}$ & \\
\hline Leverage & $\begin{array}{l}0.059 \\
(7.40)\end{array}$ & $* * *$ & $\begin{array}{l}0.059 \\
(7.38)\end{array}$ & $* * *$ & $\begin{array}{l}0.059 \\
(7.39)\end{array}$ & $* * *$ \\
\hline Size & $\begin{array}{l}-0.013 \\
-(4.35)\end{array}$ & $* * *$ & $\begin{array}{r}-0.013 \\
-(4.35)\end{array}$ & $* * *$ & $\begin{array}{l}-0.013 \\
-(4.35)\end{array}$ & $* * *$ \\
\hline$M T B$ & $\begin{array}{l}-0.033 \\
-(7.58)\end{array}$ & $* * *$ & $\begin{array}{l}-0.033 \\
-(7.57)\end{array}$ & $* * *$ & $\begin{array}{r}-0.033 \\
-(7.57)\end{array}$ & $* * *$ \\
\hline PERatio & $\begin{array}{l}-0.001 \\
-(2.99)\end{array}$ & $* * *$ & $\begin{array}{r}-0.001 \\
-(3.00)\end{array}$ & $* * *$ & $\begin{array}{l}-0.001 \\
-(3.00)\end{array}$ & $* * *$ \\
\hline InstitutionalOwnership & $\begin{array}{l}-0.049 \\
-(0.95)\end{array}$ & & $\begin{array}{r}-0.050 \\
-(0.98)\end{array}$ & & $\begin{array}{r}-0.050 \\
-(0.97)\end{array}$ & \\
\hline $\begin{array}{l}\text { Industry and Year Fixed Effects } \\
\text { Pseudo } \mathrm{R}^{2} \\
\text { Observations }\end{array}$ & $\begin{array}{r}\mathrm{Y} \\
0.043 \\
108,430 \\
\end{array}$ & & $\begin{array}{r}\mathrm{Y} \\
0.043 \\
108,430 \\
\end{array}$ & & $\begin{array}{r}\mathrm{Y} \\
0.043 \\
108,430 \\
\end{array}$ & \\
\hline $\begin{array}{l}\text { Comparison of cust. concentration coefficients }\left(\eta_{1}-\eta_{2}\right) \\
\text { t-test of }\left(\eta_{1}-\eta_{2}\right)=0 \text { : }\end{array}$ & $\begin{array}{l}-0.119 \\
-(1.90)\end{array}$ & $*$ & $\begin{array}{l}-0.025 \\
-(1.99)\end{array}$ & $* *$ & $\begin{array}{l}-0.025 \\
-(1.95)\end{array}$ & $*$ \\
\hline
\end{tabular}

This table reports results from Logit regressions relating the probability of receiving a bid to customer concentration measures and controls for Compustat firms from 1985-2016. The dependent variable is BidIndicator. See the appendix for all variable definitions. Industry fixed effects are defined at the Fama-French 48 level. Continuous variables are winsorized at 1 and 99. T-statistics (reported in parentheses) are based on standard errors clustered at the firm level. *, **, and *** denote significance at the 10 percent, 5 percent, and 1 percent level, respectively. 
Table 5, cont.

Government and non-government customer concentration

Panel B: Payment method (using full payment method sample)

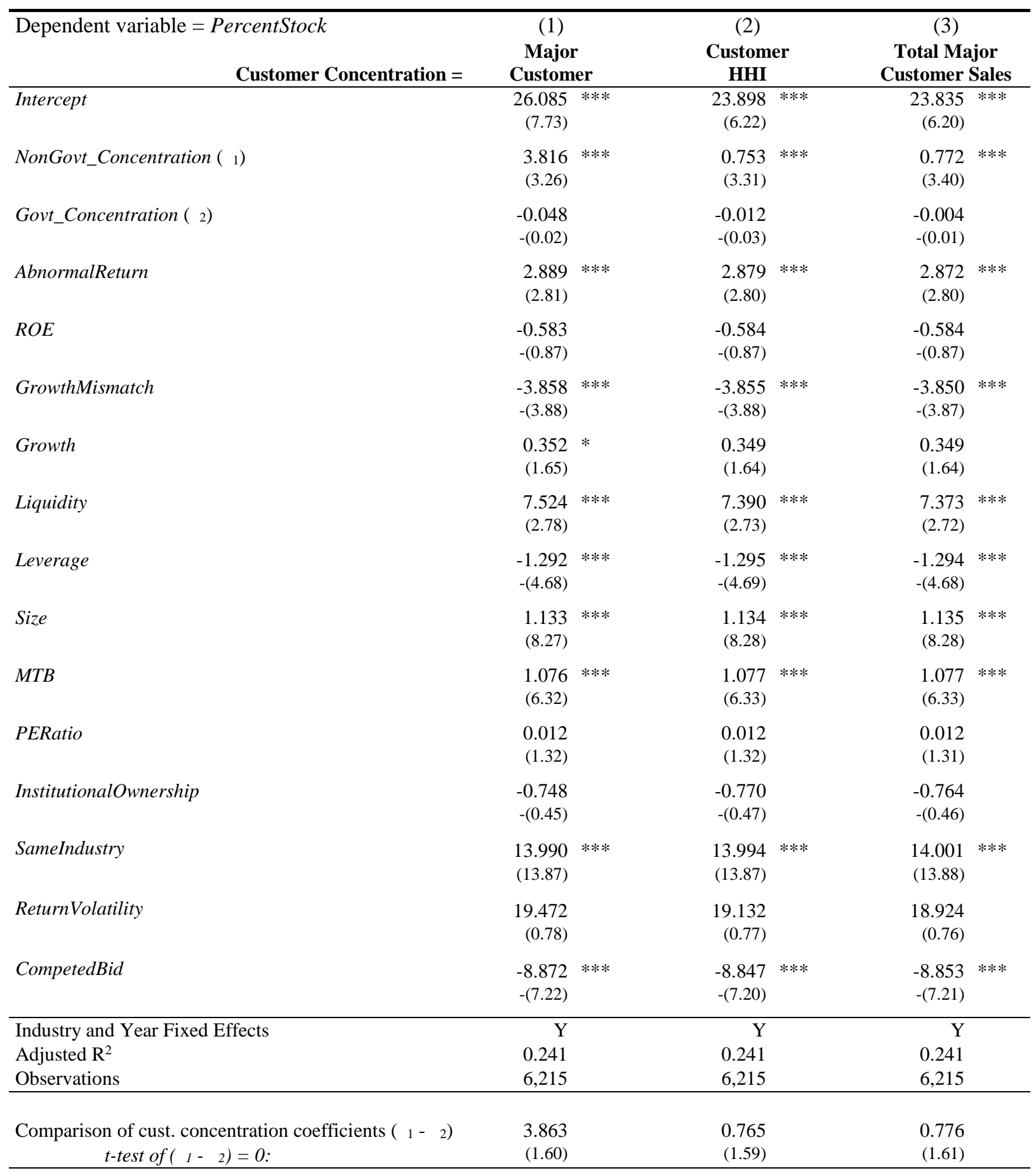

This table reports results from OLS regressions relating the payment method to customer concentration measures and controls for bid offers from 1985-2016. The dependent variable is Percent Stock. See the appendix for all variable definitions. Industry fixed effects are defined at the Fama-French 48 level. Continuous variables are winsorized at 1 and 99. T-statistics (reported in parentheses) are based on standard errors clustered at the firm level. *, **, and *** denote significance at the 10 percent, 5 percent, and 1 percent level, respectively. 
Table 5, cont.

Government and non-government customer concentration

Panel C: Payment method (using public acquirer sample)

\begin{tabular}{|c|c|c|c|c|c|c|}
\hline \multirow{2}{*}{$\begin{array}{l}\text { Dependent variable }=\text { Percent } \text { Stock } \\
\qquad \text { Customer Concentration = } \\
\text { Customer concentration variables }\end{array}$} & \multicolumn{2}{|c|}{$\begin{array}{c}(1) \\
\text { Major } \\
\text { Customer }\end{array}$} & \multicolumn{2}{|c|}{$\begin{array}{c}(2) \\
\text { Customer } \\
\text { HHI }\end{array}$} & \multicolumn{2}{|c|}{$\begin{array}{c}(3) \\
\text { Total Major } \\
\text { Customer Sales }\end{array}$} \\
\hline & & & & & & \\
\hline NonGovt_Concentration $\left(\lambda_{1}\right)$ & $\begin{array}{l}-3.845 \\
-(1.15)\end{array}$ & & $\begin{array}{l}-0.617 \\
-(0.97)\end{array}$ & & $\begin{array}{l}-0.565 \\
-(0.90)\end{array}$ & \\
\hline NonGovt_Concentration $*$ RelativeSize $\left(\lambda_{2}\right)$ & $\begin{array}{r}14.281 \\
(2.50)\end{array}$ & $* *$ & $\begin{array}{l}2.726 \\
(2.51)\end{array}$ & $* *$ & $\begin{array}{l}2.629 \\
(2.44)\end{array}$ & $* *$ \\
\hline Govt_Concentration $\left(\lambda_{3}\right)$ & $\begin{array}{l}0.670 \\
(0.09)\end{array}$ & & $\begin{array}{l}0.190 \\
(0.13)\end{array}$ & & $\begin{array}{l}0.209 \\
(0.14)\end{array}$ & \\
\hline Govt_Concentration $*$ RelativeSize $\left(\lambda_{4}\right)$ & $\begin{array}{l}-9.028 \\
-(0.75)\end{array}$ & & $\begin{array}{l}-1.849 \\
-(0.77)\end{array}$ & & $\begin{array}{l}-1.885 \\
-(0.78)\end{array}$ & \\
\hline \multicolumn{7}{|l|}{ Acquirer controls } \\
\hline AcquirerSales & $\begin{array}{l}-0.097 \\
-(2.30)\end{array}$ & $* *$ & $\begin{array}{l}-0.097 \\
-(2.28)\end{array}$ & $* *$ & $\begin{array}{l}-0.097 \\
-(2.28)\end{array}$ & $* *$ \\
\hline AcquirerROA & $\begin{array}{r}-19.923 \\
-(2.84)\end{array}$ & $* * *$ & $\begin{array}{r}-19.847 \\
-(2.81)\end{array}$ & $* * *$ & $\begin{array}{r}-19.817 \\
-(2.81)\end{array}$ & $* * *$ \\
\hline AcquirerMTB & $\begin{array}{l}0.003 \\
(0.34)\end{array}$ & & $\begin{array}{l}0.003 \\
(0.33)\end{array}$ & & $\begin{array}{l}0.003 \\
(0.34)\end{array}$ & \\
\hline RelativeSize & $\begin{array}{r}25.879 \\
(7.06)\end{array}$ & $* * *$ & $\begin{array}{r}25.207 \\
(2.02)\end{array}$ & $* *$ & $\begin{array}{r}25.799 \\
(2.06)\end{array}$ & $* *$ \\
\hline \multicolumn{7}{|l|}{ Target controls } \\
\hline $\begin{array}{l}\text { AbnormalReturn } \\
\text { ROE } \\
\text { GrowthMismatch } \\
\text { Growth } \\
\text { Liquidity } \\
\text { Leverage } \\
\text { Size } \\
\text { MTB } \\
\text { PERatio } \\
\text { InstitutionalOwnership } \\
\text { Same Industry } \\
\text { ReturnVolatility } \\
\text { Competed Bid }\end{array}$ & $\begin{array}{r}2.303 \\
-0.778 \\
-4.866 \\
-0.188 \\
8.105 \\
-1.647 \\
0.968 \\
1.131 \\
0.021 \\
-3.703 \\
2.227 \\
41.308 \\
-13.545\end{array}$ & $\begin{array}{l} \\
* * * \\
* * * \\
* * * \\
* * *\end{array}$ & $\begin{array}{r}2.330 \\
-0.784 \\
-4.847 \\
-0.190 \\
7.929 \\
-1.646 \\
0.969 \\
1.127 \\
0.021 \\
-3.721 \\
2.274 \\
40.404 \\
-13.497\end{array}$ & $\begin{array}{l}* * * \\
* \\
* * * \\
* * * \\
* * *\end{array}$ & $\begin{array}{r}2.311 \\
-0.787 \\
-4.840 \\
-0.187 \\
7.880 \\
-1.647 \\
0.968 \\
1.129 \\
0.021 \\
-3.698 \\
2.288 \\
40.259 \\
-13.509\end{array}$ & $\begin{array}{l} \\
* * * \\
* \\
* * * \\
* * * \\
* * *\end{array}$ \\
\hline $\begin{array}{l}\text { Industry and Year Fixed Effects } \\
\text { Adjusted } \mathrm{R}^{2} \\
\text { Observations }\end{array}$ & $\begin{array}{r}\mathrm{Y} \\
0.277 \\
2,310 \\
\end{array}$ & & $\begin{array}{r}\mathrm{Y} \\
0.277 \\
2,310 \\
\end{array}$ & & $\begin{array}{r}\mathrm{Y} \\
0.277 \\
2,310 \\
\end{array}$ & \\
\hline $\begin{array}{l}\text { Comparison of total effects of non-government and } \\
\text { government concentration }\left(\lambda_{1}+\lambda_{2}\right)-\left(\lambda_{3}+\lambda_{4}\right) \\
\text { t-test of }\left[\left(\lambda_{1}+\lambda_{2}\right)-\left(\lambda_{3}+\lambda_{4}\right)\right]=0 \text { : }\end{array}$ & $\begin{array}{r}18.794 \\
(2.40) \\
\end{array}$ & $* *$ & $\begin{array}{l}3.768 \\
(2.42) \\
\end{array}$ & $* *$ & $\begin{array}{l}3.740 \\
(2.40) \\
\end{array}$ & \\
\hline $\begin{array}{l}\text { This table reports results from OLS regressions relating the payn } \\
\text { from 1985-2016. The dependent variable is Percent Stock. See th } \\
\text { the Fama-French } 48 \text { level. Continuous variables are winsorized } \\
\text { clustered at the firm level. *, **, and } * * * \text { denote significance at } \\
\text { intercepts and t-stats for target controls have been repressed. }\end{array}$ & $\begin{array}{l}\text { method to } \\
\text { pendix for } \\
\text { and } 99 \text {. T-st } \\
0 \text { percent, } 5\end{array}$ & $\begin{array}{l}\text { custo } \\
\text { all vi } \\
\text { tatisti } \\
5 \text { per }\end{array}$ & $\begin{array}{l}\text { ration mea } \\
\text { itions. Indu } \\
\text { in parenth } \\
\text { ercent leve }\end{array}$ & $\begin{array}{l}\text { asure } \\
\text { ustry } \\
\text { eses } \\
\text { el, re }\end{array}$ & $\begin{array}{l}\text { trols for bid of } \\
\text { ects are define } \\
\text { on standard } \\
\text { For brevity, }\end{array}$ & $\begin{array}{l}\text { ffers } \\
\text { ed at } \\
\text { errors }\end{array}$ \\
\hline
\end{tabular}




\section{Table 6}

Customer concentration and switching costs

Panel A: Bid likelihood

\begin{tabular}{|c|c|c|c|c|c|c|}
\hline \multirow[t]{2}{*}{$\begin{array}{l}\text { Dependent variable }=\text { BidIndicator } \\
\qquad \text { Customer Concentration = }\end{array}$} & \multicolumn{2}{|c|}{$\begin{array}{c}(1) \\
\text { Major } \\
\text { Customer }\end{array}$} & \multicolumn{2}{|c|}{$\begin{array}{l}(2) \\
\text { Customer } \\
\text { HHI }\end{array}$} & \multicolumn{2}{|c|}{$\begin{array}{c}\text { (3) } \\
\text { Total Major } \\
\text { Customer Sales }\end{array}$} \\
\hline & $\begin{array}{r}-2.864 \\
-(50.72)\end{array}$ & $* * *$ & $\begin{array}{r}-2.672 \\
-(36.37)\end{array}$ & $* * *$ & $\begin{array}{r}-2.687 \\
-(36.46)\end{array}$ & $* * *$ \\
\hline CustomerConcentration $\left(v_{1}\right)$ & $\begin{array}{l}-0.323 \\
-(6.35)\end{array}$ & $* * *$ & $\begin{array}{l}-0.067 \\
-(6.46)\end{array}$ & $* * *$ & $\begin{array}{l}-0.064 \\
-(6.16)\end{array}$ & $* * *$ \\
\hline SwitchingCosts $\left(v_{2}\right)$ & $\begin{array}{l}0.351 \\
(4.31)\end{array}$ & $* * *$ & $\begin{array}{l}-0.005 \\
-(0.04)\end{array}$ & & $\begin{array}{l}0.010 \\
(0.08)\end{array}$ & \\
\hline CustomerConcentration $*$ Switching Costs $\left(v_{3}\right)$ & $\begin{array}{l}0.547 \\
(5.94)\end{array}$ & $* * *$ & $\begin{array}{l}0.119 \\
(6.24)\end{array}$ & $* * *$ & $\begin{array}{l}0.116 \\
(6.08)\end{array}$ & $* * *$ \\
\hline AbnormalReturn & $\begin{array}{l}-0.129 \\
-(4.97)\end{array}$ & $* * *$ & $\begin{array}{l}-0.130 \\
-(4.98)\end{array}$ & $* * *$ & $\begin{array}{l}-0.130 \\
-(4.97)\end{array}$ & $* * *$ \\
\hline$R O E$ & $\begin{array}{l}-0.045 \\
-(2.45)\end{array}$ & $* *$ & $\begin{array}{l}-0.045 \\
-(2.44)\end{array}$ & $* *$ & $\begin{array}{l}-0.045 \\
-(2.43)\end{array}$ & $* *$ \\
\hline GrowthMismatch & $\begin{array}{l}0.015 \\
(0.50)\end{array}$ & & $\begin{array}{l}0.015 \\
(0.50)\end{array}$ & & $\begin{array}{l}0.015 \\
(0.51)\end{array}$ & \\
\hline Growth & $\begin{array}{l}-0.006 \\
-(1.59)\end{array}$ & & $\begin{array}{l}-0.006 \\
-(1.58)\end{array}$ & & $\begin{array}{l}-0.006 \\
-(1.58)\end{array}$ & \\
\hline Liquidity & $\begin{array}{l}0.205 \\
(2.86)\end{array}$ & $* * *$ & $\begin{array}{l}0.212 \\
(2.96)\end{array}$ & $* * *$ & $\begin{array}{l}0.211 \\
(2.96)\end{array}$ & $* * *$ \\
\hline Leverage & $\begin{array}{l}0.054 \\
(6.70)\end{array}$ & $* * *$ & $\begin{array}{l}0.054 \\
(6.68)\end{array}$ & $* * *$ & $\begin{array}{c}0.054 \\
(6.70)\end{array}$ & $* * *$ \\
\hline Size & $\begin{array}{l}-0.020 \\
-(4.20)\end{array}$ & $* * *$ & $\begin{array}{l}-0.019 \\
-(4.20)\end{array}$ & $* * *$ & $\begin{array}{l}-0.019 \\
-(4.20)\end{array}$ & $* * *$ \\
\hline$M T B$ & $\begin{array}{l}-0.033 \\
-(7.48)\end{array}$ & $* * *$ & $\begin{array}{l}-0.033 \\
-(7.45)\end{array}$ & $* * *$ & $\begin{array}{l}-0.033 \\
-(7.46)\end{array}$ & $* * *$ \\
\hline PERatio & $\begin{array}{l}-0.001 \\
-(3.37)\end{array}$ & $* * *$ & $\begin{array}{l}-0.001 \\
-(3.40)\end{array}$ & $* * *$ & $\begin{array}{l}-0.001 \\
-(3.40)\end{array}$ & $* * *$ \\
\hline InstitutionalOwnership & $\begin{array}{l}-0.174 \\
-(3.25)\end{array}$ & $* * *$ & $\begin{array}{l}-0.176 \\
-(3.27)\end{array}$ & $* * *$ & $\begin{array}{l}-0.176 \\
-(3.27)\end{array}$ & $* * *$ \\
\hline $\begin{array}{l}\text { Industry and Year Fixed Effects } \\
\text { Pseudo } \mathrm{R}^{2} \\
\text { Observations }\end{array}$ & $\begin{array}{r}\mathrm{Y} \\
0.046 \\
108,430\end{array}$ & & $\begin{array}{r}\mathrm{Y} \\
0.046 \\
108,430\end{array}$ & & $\begin{array}{r}\mathrm{Y} \\
0.046 \\
108,430\end{array}$ & \\
\hline $\begin{array}{l}\text { Total effect of customer concentration }\left(v_{1}+v_{3}\right) \\
t \text {-test of }\left(v_{1}+v_{3}\right)=0 \text { : }\end{array}$ & $\begin{array}{l}0.224 \\
(3.68)\end{array}$ & $* * *$ & $\begin{array}{r}0.053 \\
(4.08)\end{array}$ & $* * *$ & $\begin{array}{l}0.053 \\
(4.08)\end{array}$ & $* * *$ \\
\hline
\end{tabular}

This table reports results from Logit regressions relating the probability of receiving a bid to customer concentration measures and controls for Compustat firms from 1985-2016. The dependent variable is BidIndicator. See the appendix for all variable definitions. Industry fixed effects are defined at the Fama-French 48 level. Continuous variables are winsorized at 1 and 99. T-statistics (reported in parentheses) are based on standard errors clustered at the firm level. *,**, and *** denote significance at the 10 percent, 5 percent, and 1 percent level, respectively. 
Table 6, cont.

Customer concentration and switching costs

Panel B: Payment method (using full payment method sample)

\begin{tabular}{|c|c|c|c|c|c|c|}
\hline \multirow[t]{2}{*}{$\begin{array}{l}\text { Dependent variable }=\text { PercentStock } \\
\qquad \text { Customer Concentration = }\end{array}$} & \multicolumn{2}{|c|}{$\begin{array}{c}\text { (1) } \\
\text { Major } \\
\text { Customer }\end{array}$} & \multicolumn{2}{|c|}{$\begin{array}{l}(2) \\
\text { Customer } \\
\text { HHI }\end{array}$} & \multicolumn{2}{|c|}{$\begin{array}{c}(3) \\
\text { Total Major } \\
\text { Customer Sales }\end{array}$} \\
\hline & $\begin{array}{r}22.485 \\
(6.51)\end{array}$ & **** & $\begin{array}{r}19.938 \\
(5.39)\end{array}$ & $* * *$ & $\begin{array}{r}19.890 \\
(5.38)\end{array}$ & **** \\
\hline CustomerConcentration $\left(\delta_{1}\right)$ & $\begin{array}{l}5.720 \\
(2.80)\end{array}$ & $* * *$ & $\begin{array}{l}0.905 \\
(2.22)\end{array}$ & $* *$ & $\begin{array}{l}0.950 \\
(2.34)\end{array}$ & $* *$ \\
\hline SwitchingCosts $\left(\delta_{2}\right)$ & $\begin{array}{r}12.193 \\
(4.11)\end{array}$ & $* * *$ & $\begin{array}{r}12.899 \\
(2.94)\end{array}$ & $* * *$ & $\begin{array}{r}12.888 \\
(2.93)\end{array}$ & $* * *$ \\
\hline CustomerConcentration $*$ Switching Costs $\left(\delta_{3}\right)$ & $\begin{array}{l}-4.784 \\
-(1.31)\end{array}$ & & $\begin{array}{l}-0.508 \\
-(0.68)\end{array}$ & & $\begin{array}{l}-0.502 \\
-(0.68)\end{array}$ & \\
\hline AbnormalReturn & $\begin{array}{l}3.062 \\
(2.97)\end{array}$ & $* * *$ & $\begin{array}{l}3.056 \\
(2.97)\end{array}$ & $* * *$ & $\begin{array}{l}3.067 \\
(2.98)\end{array}$ & $* * *$ \\
\hline$R O E$ & $\begin{array}{l}-0.785 \\
-(1.16)\end{array}$ & & $\begin{array}{l}-0.806 \\
-(1.19)\end{array}$ & & $\begin{array}{l}-0.808 \\
-(1.19)\end{array}$ & \\
\hline GrowthMismatch & $\begin{array}{l}-3.677 \\
-(3.70)\end{array}$ & $* * *$ & $\begin{array}{l}-3.674 \\
-(3.70)\end{array}$ & $* * *$ & $\begin{array}{l}-3.666 \\
-(3.69)\end{array}$ & $* * *$ \\
\hline Growth & $\begin{array}{l}0.324 \\
(1.55)\end{array}$ & & $\begin{array}{l}0.321 \\
(1.54)\end{array}$ & & $\begin{array}{l}0.321 \\
(1.54)\end{array}$ & \\
\hline Liquidity & $\begin{array}{r}10.241 \\
(3.66)\end{array}$ & $* * *$ & $\begin{array}{r}10.152 \\
(3.63)\end{array}$ & $* * *$ & $\begin{array}{r}10.161 \\
(3.63)\end{array}$ & $* * *$ \\
\hline Leverage & $\begin{array}{l}-1.354 \\
-(4.89)\end{array}$ & $* * *$ & $\begin{array}{l}-1.363 \\
-(4.92)\end{array}$ & $* * *$ & $\begin{array}{l}-1.363 \\
-(4.92)\end{array}$ & $* * *$ \\
\hline Size & $\begin{array}{l}0.913 \\
(6.73)\end{array}$ & $* * *$ & $\begin{array}{l}0.921 \\
(6.78)\end{array}$ & $* * *$ & $\begin{array}{l}0.923 \\
(6.79)\end{array}$ & $* * *$ \\
\hline$M T B$ & $\begin{array}{l}1.074 \\
(6.34)\end{array}$ & $* * *$ & $\begin{array}{l}1.077 \\
(6.35)\end{array}$ & $* * *$ & $\begin{array}{l}1.077 \\
(6.35)\end{array}$ & $* * *$ \\
\hline PERatio & $\begin{array}{l}0.011 \\
(1.24)\end{array}$ & & $\begin{array}{l}0.011 \\
(1.25)\end{array}$ & & $\begin{array}{l}0.011 \\
(1.25)\end{array}$ & \\
\hline InstitutionalOwnership & $\begin{array}{l}-1.695 \\
-(1.02)\end{array}$ & & $\begin{array}{l}-1.675 \\
-(1.01)\end{array}$ & & $\begin{array}{l}-1.687 \\
-(1.01)\end{array}$ & \\
\hline SameIndustry & $\begin{array}{l}13.962 \\
(13.83)\end{array}$ & $* * *$ & $\begin{array}{l}13.963 \\
(13.83)\end{array}$ & $* * *$ & $\begin{array}{l}13.968 \\
(13.84)\end{array}$ & $* * *$ \\
\hline ReturnVolatility & $\begin{array}{r}52.413 \\
(1.99)\end{array}$ & $* *$ & $\begin{array}{r}52.988 \\
(2.01)\end{array}$ & $* *$ & $\begin{array}{r}52.811 \\
(2.00)\end{array}$ & $* *$ \\
\hline CompetedBid & $\begin{array}{l}-9.343 \\
-(7.63)\end{array}$ & $* * *$ & $\begin{array}{l}-9.323 \\
-(7.60)\end{array}$ & $* * *$ & $\begin{array}{l}-9.329 \\
-(7.61)\end{array}$ & $* * *$ \\
\hline $\begin{array}{l}\text { Industry and Year Fixed Effects } \\
\text { Adjusted } \mathrm{R}^{2} \\
\text { Observations }\end{array}$ & $\begin{array}{r}\mathrm{Y} \\
0.243 \\
6,215 \\
\end{array}$ & & $\begin{array}{r}Y \\
0.242 \\
6,215 \\
\end{array}$ & & $\begin{array}{r} \\
0.243 \\
6,215 \\
\end{array}$ & \\
\hline $\begin{array}{l}\text { Total effect of customer concentration }\left(\delta_{1}+\delta_{3}\right) \\
\text { t-test of }\left(\delta_{l}+\delta_{3}\right)=0 \text { : }\end{array}$ & $\begin{array}{l}0.936 \\
(0.42)\end{array}$ & & $\begin{array}{l}0.398 \\
(0.86)\end{array}$ & & $\begin{array}{r}0.448 \\
(0.97)\end{array}$ & \\
\hline
\end{tabular}

This table reports results from OLS regressions relating the payment method to customer concentration measures and controls for bid offers from 1985-2016. The dependent variable is Percent Stock. See the appendix for all variable definitions. Industry fixed effects are defined at the Fama-French 48 level. Continuous variables are winsorized at 1 and 99. T-statistics (reported in parentheses) are based on standard errors clustered at the firm level. *,**, and *** denote significance at the 10 percent, 5 percent, and 1 percent level, respectively. 
Table 6, cont.

Customer concentration and switching costs

Panel C: Payment method (using public acquirer sample)

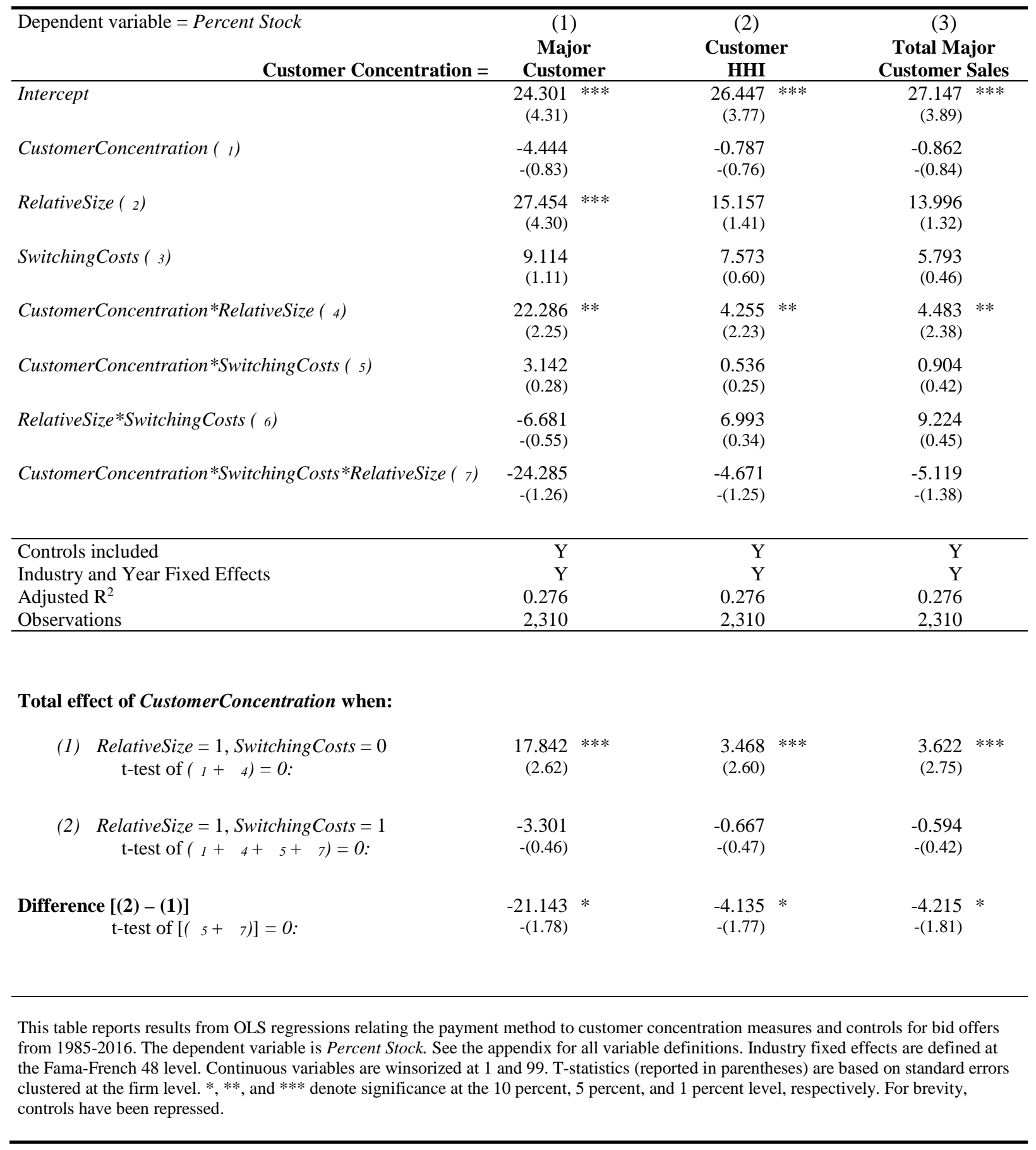




\section{Table 7}

\section{Customer concentration and relationship age}

\section{Panel A: Bid likelihood}

\begin{tabular}{|c|c|c|c|c|c|c|}
\hline \multirow{2}{*}{$\begin{array}{l}\text { Dependent variable }=\text { BidIndicator } \\
\qquad \text { Customer Concentration = } \\
\text { Intercept }\end{array}$} & \multicolumn{2}{|c|}{$\begin{array}{c}\text { (1) } \\
\text { Major } \\
\text { Customer }\end{array}$} & \multicolumn{2}{|c|}{$\begin{array}{l}(2) \\
\text { Customer } \\
\text { HHI }\end{array}$} & \multicolumn{2}{|c|}{$\begin{array}{c}(3) \\
\text { Total Major } \\
\text { Customer Sales }\end{array}$} \\
\hline & $\begin{array}{r}-2.652 \\
-(71.58)\end{array}$ & **** & $\begin{array}{r}-2.667 \\
-(40.43)\end{array}$ & $* * *$ & $\begin{array}{r}-2.666 \\
-(40.42)\end{array}$ & $* * *$ \\
\hline CustomerConcentration_Long $\left(\rho_{1}\right)$ & $\begin{array}{l}0.080 \\
(1.83)\end{array}$ & $*$ & $\begin{array}{l}0.016 \\
(1.83)\end{array}$ & $*$ & $\begin{array}{l}0.016 \\
(1.82)\end{array}$ & $*$ \\
\hline CustomerConcentration_Short $\left(\rho_{2}\right)$ & $\begin{array}{l}-0.087 \\
-(2.50)\end{array}$ & $* *$ & $\begin{array}{l}-0.016 \\
-(2.51)\end{array}$ & $* *$ & $\begin{array}{l}-0.017 \\
-(2.57)\end{array}$ & $* *$ \\
\hline AbnormalReturn & $\begin{array}{l}-0.121 \\
-(4.80)\end{array}$ & $* * *$ & $\begin{array}{l}-0.121 \\
-(4.80)\end{array}$ & $* * *$ & $\begin{array}{l}-0.121 \\
-(4.80)\end{array}$ & $* * *$ \\
\hline$R O E$ & $\begin{array}{l}-0.019 \\
-(1.07)\end{array}$ & & $\begin{array}{l}-0.019 \\
-(1.07)\end{array}$ & & $\begin{array}{l}-0.020 \\
-(1.07)\end{array}$ & \\
\hline GrowthMismatch & $\begin{array}{l}0.008 \\
(0.29)\end{array}$ & & $\begin{array}{l}0.008 \\
(0.29)\end{array}$ & & $\begin{array}{l}0.008 \\
(0.29)\end{array}$ & \\
\hline Growth & $\begin{array}{l}-0.007 \\
-(1.63)\end{array}$ & & $\begin{array}{l}-0.007 \\
-(1.63)\end{array}$ & & $\begin{array}{l}-0.007 \\
-(1.63)\end{array}$ & \\
\hline Liquidity & $\begin{array}{l}0.077 \\
(1.12)\end{array}$ & & $\begin{array}{l}0.078 \\
(1.13)\end{array}$ & & $\begin{array}{l}0.078 \\
(1.13)\end{array}$ & \\
\hline Leverage & $\begin{array}{l}0.060 \\
(7.45)\end{array}$ & $* * *$ & $\begin{array}{l}0.060 \\
(7.45)\end{array}$ & $* * *$ & $\begin{array}{l}0.060 \\
(7.45)\end{array}$ & $* * *$ \\
\hline Size & $\begin{array}{l}-0.013 \\
-(4.32)\end{array}$ & $* * *$ & $\begin{array}{l}-0.013 \\
-(4.32)\end{array}$ & $* * *$ & $\begin{array}{l}-0.013 \\
-(4.32)\end{array}$ & $* * *$ \\
\hline$M T B$ & $\begin{array}{l}-0.033 \\
-(7.62)\end{array}$ & $* * *$ & $\begin{array}{l}-0.033 \\
-(7.62)\end{array}$ & $* * *$ & $\begin{array}{l}-0.033 \\
-(7.62)\end{array}$ & $* * *$ \\
\hline PERatio & $\begin{array}{l}-0.001 \\
-(2.96)\end{array}$ & $* * *$ & $\begin{array}{l}-0.001 \\
-(2.96)\end{array}$ & $* * *$ & $\begin{array}{l}-0.001 \\
-(2.96)\end{array}$ & $* * *$ \\
\hline InstitutionalOwnership & $\begin{array}{l}-0.044 \\
-(0.86)\end{array}$ & & $\begin{array}{l}-0.045 \\
-(0.87)\end{array}$ & & $\begin{array}{l}-0.045 \\
-(0.87)\end{array}$ & \\
\hline $\begin{array}{l}\text { Industry and Year Fixed Effects } \\
\text { Pseudo } \mathrm{R}^{2} \\
\text { Observations }\end{array}$ & $\begin{array}{r}\mathrm{Y} \\
0.043 \\
108,430 \\
\end{array}$ & & $\begin{array}{r}\mathrm{Y} \\
0.043 \\
108,430\end{array}$ & & $\begin{array}{r}\mathrm{Y} \\
0.043 \\
108,430 \\
\end{array}$ & \\
\hline $\begin{array}{l}\text { Comparison of cust. concentration coefficients }\left(\rho_{1}-\rho_{2}\right) \\
\text { t-test of }\left(\rho_{1}-\rho_{2}\right)=0 \text { : }\end{array}$ & $\begin{array}{l}0.167 \\
(3.52)\end{array}$ & $* * *$ & $\begin{array}{l}0.033 \\
(3.46)\end{array}$ & $* * *$ & $\begin{array}{l}0.033 \\
(3.49)\end{array}$ & $* * *$ \\
\hline
\end{tabular}

This table reports results from Logit regressions relating the probability of receiving a bid to customer concentration measures and controls for Compustat firms from 1985-2016. The dependent variable is BidIndicator. See the appendix for all variable definitions. Industry fixed effects are defined at the Fama-French 48 level. Continuous variables are winsorized at 1 and 99. T-statistics (reported in parentheses) are based on standard errors clustered at the firm level. *,**, and *** denote significance at the 10 percent, 5 percent, and 1 percent level, respectively. 
Table 7, cont.

Customer concentration and relationship age

Panel B: Payment method (using the full payment method sample)

\begin{tabular}{|c|c|c|c|c|c|c|}
\hline \multirow{2}{*}{ 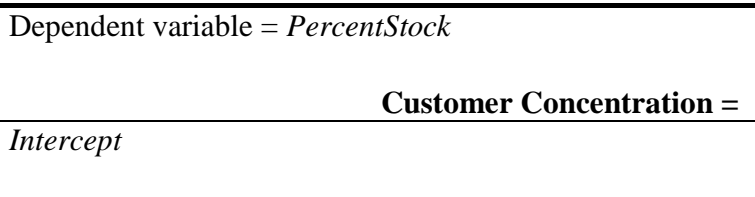 } & \multicolumn{2}{|c|}{$\begin{array}{c}(1) \\
\text { Major } \\
\text { Customer }\end{array}$} & \multicolumn{2}{|c|}{$\begin{array}{l}\text { (2) } \\
\text { Customer } \\
\text { HHI }\end{array}$} & \multicolumn{2}{|c|}{$\begin{array}{c}(3) \\
\text { Total Major } \\
\text { Customer Sales }\end{array}$} \\
\hline & $\begin{array}{r}24.648 \\
(7.34)\end{array}$ & $* * *$ & $\begin{array}{r}21.440 \\
(5.64)\end{array}$ & $* * *$ & $\begin{array}{r}21.439 \\
(5.64)\end{array}$ & $* * *$ \\
\hline CustomerConcentration_Long ( 1 ) & $\begin{array}{l}1.332 \\
(0.86)\end{array}$ & & $\begin{array}{l}0.284 \\
(0.90)\end{array}$ & & $\begin{array}{l}0.283 \\
(0.90)\end{array}$ & \\
\hline CustomerConcentration_Short ( 2 ) & $\begin{array}{l}3.695 \\
(2.85)\end{array}$ & $* * *$ & $\begin{array}{l}0.687 \\
(2.83)\end{array}$ & $* * *$ & $\begin{array}{l}0.686 \\
(2.83)\end{array}$ & $* * *$ \\
\hline AbnormalReturn & $\begin{array}{l}2.874 \\
(2.80)\end{array}$ & $* * *$ & $\begin{array}{l}2.872 \\
(2.80)\end{array}$ & $* * *$ & $\begin{array}{l}2.871 \\
(2.80)\end{array}$ & $* * *$ \\
\hline$R O E$ & $\begin{array}{l}-0.573 \\
-(0.85)\end{array}$ & & $\begin{array}{l}-0.574 \\
-(0.85)\end{array}$ & & $\begin{array}{l}-0.575 \\
-(0.85)\end{array}$ & \\
\hline GrowthMismatch & $\begin{array}{l}-3.903 \\
-(3.93)\end{array}$ & $* * *$ & $\begin{array}{l}-3.894 \\
-(3.92)\end{array}$ & $* * *$ & $\begin{array}{l}-3.897 \\
-(3.92)\end{array}$ & $* * *$ \\
\hline Growth & $\begin{array}{l}0.351 \\
(1.63)\end{array}$ & & $\begin{array}{l}0.349 \\
(1.63)\end{array}$ & & $\begin{array}{l}0.349 \\
(1.63)\end{array}$ & \\
\hline Liquidity & $\begin{array}{l}0.000 \\
(2.83)\end{array}$ & $* * *$ & $\begin{array}{l}0.000 \\
(2.81)\end{array}$ & $* * *$ & $\begin{array}{l}0.000 \\
(2.81)\end{array}$ & $* * *$ \\
\hline Leverage & $\begin{array}{l}-1.314 \\
-(4.73)\end{array}$ & $* * *$ & $\begin{array}{l}-1.316 \\
-(4.74)\end{array}$ & $* * *$ & $\begin{array}{l}-1.316 \\
-(4.74)\end{array}$ & $* * *$ \\
\hline Size & $\begin{array}{l}1.132 \\
(8.34)\end{array}$ & $* * *$ & $\begin{array}{l}1.132 \\
(8.33)\end{array}$ & $* * *$ & $\begin{array}{l}1.132 \\
(8.33)\end{array}$ & $* * *$ \\
\hline$M T B$ & $\begin{array}{l}1.085 \\
(6.32)\end{array}$ & $* * *$ & $\begin{array}{l}1.086 \\
(6.33)\end{array}$ & $* * *$ & $\begin{array}{l}1.086 \\
(6.33)\end{array}$ & $* * *$ \\
\hline PERatio & $\begin{array}{l}0.012 \\
(1.29)\end{array}$ & & $\begin{array}{l}0.011 \\
(1.28)\end{array}$ & & $\begin{array}{l}0.011 \\
(1.28)\end{array}$ & \\
\hline InstitutionalOwnership & $\begin{array}{l}-0.698 \\
-(0.42)\end{array}$ & & $\begin{array}{l}-0.686 \\
-(0.42)\end{array}$ & & $\begin{array}{l}-0.689 \\
-(0.42)\end{array}$ & \\
\hline Same Industry & $\begin{array}{r}13.930 \\
(13.80)\end{array}$ & $* * *$ & $\begin{array}{l}13.931 \\
(13.80)\end{array}$ & $* * *$ & $\begin{array}{r}13.932 \\
(13.80)\end{array}$ & $* * *$ \\
\hline Return Volatility & $\begin{array}{r}22.916 \\
(0.92)\end{array}$ & & $\begin{array}{r}22.816 \\
(0.92)\end{array}$ & & $\begin{array}{r}22.816 \\
(0.92)\end{array}$ & \\
\hline Competed Bid & $\begin{array}{l}-8.889 \\
-(7.23)\end{array}$ & $* * *$ & $\begin{array}{l}-8.874 \\
-(7.21)\end{array}$ & $* * *$ & $\begin{array}{l}-8.871 \\
-(7.21)\end{array}$ & $* * *$ \\
\hline $\begin{array}{l}\text { Industry and Year Fixed Effects } \\
\text { Adjusted } \mathrm{R}^{2} \\
\text { Observations }\end{array}$ & $\begin{array}{r}\mathrm{Y} \\
0.241 \\
6,215 \\
\end{array}$ & & $\begin{array}{r}\mathrm{Y} \\
0.241 \\
6,215 \\
\end{array}$ & & $\begin{array}{r}\mathrm{Y} \\
0.241 \\
6,215 \\
\end{array}$ & \\
\hline $\begin{array}{l}\text { Comparison of cust. concentration coefficients }\left(\begin{array}{ll}1- & 2\end{array}\right) \\
\text { t-test of }\left(\begin{array}{ll}1- & 2\end{array}\right)=0 \text { : }\end{array}$ & $\begin{array}{l}-2.364 \\
-(1.36) \\
\end{array}$ & & $\begin{array}{r}-0.403 \\
-(1.17) \\
\end{array}$ & & $\begin{array}{l}-0.403 \\
-(1.17) \\
\end{array}$ & \\
\hline $\begin{array}{l}\text { This table reports results from OLS regressions relating the payme } \\
\text { from 1985-2016.The dependent variable is Percent Stock. See the } \\
\text { Fama-French } 48 \text { level. Continuous variables are winsorized at } 1 \text { an } \\
\text { clustered at the firm level. *,**, and } * * * \text { denote significance at the }\end{array}$ & $\begin{array}{l}\text { method to } \\
\text { gendix for } \\
9 \text {. T-statis } \\
\text { percent, }\end{array}$ & $\begin{array}{l}\text { custc } \\
\text { all va } \\
\text { stics } \\
5 \text { per }\end{array}$ & $\begin{array}{l}\text { tration mea } \\
\text { tions. Indu } \\
\text { arentheses } \\
\text { ercent leve }\end{array}$ & $\begin{array}{l}\text { asures } \\
\text { ustry } \\
\text { s) are } \\
\text { el, res }\end{array}$ & $\begin{array}{l}\text { trols for bid of } \\
\text { ects are defined } \\
\text { standard erro } \\
\text { y. }\end{array}$ & $\begin{array}{l}\text { ffers } \\
\text { d at the } \\
\text { ors }\end{array}$ \\
\hline
\end{tabular}




\section{Table 8}

Instrumental variable analysis - Bid likelihood

Panel A: First stage

\begin{tabular}{|c|c|c|c|c|c|c|}
\hline \multirow{2}{*}{$\begin{array}{l}\text { Dependent variables }=\text { Customer Concentration } \\
\qquad \text { Customer Concentration = } \\
\text { Intercept }\end{array}$} & \multicolumn{2}{|c|}{$\begin{array}{c}(1) \\
\text { Major } \\
\text { Customer }\end{array}$} & \multicolumn{2}{|c|}{$\begin{array}{l}(2) \\
\text { Customer } \\
\text { HHI }\end{array}$} & \multicolumn{2}{|c|}{$\begin{array}{c}(3) \\
\text { Total Major } \\
\text { Customer Sales }\end{array}$} \\
\hline & $\begin{array}{r}0.322 \\
(13.27)\end{array}$ & $* * *$ & $\begin{array}{r}2.862 \\
(23.22)\end{array}$ & $* * *$ & $\begin{array}{r}2.822 \\
(22.97)\end{array}$ & $* * *$ \\
\hline Industry Concentration $t-2$ & $\begin{array}{r}0.395 \\
(27.05)\end{array}$ & $* * *$ & $\begin{array}{r}0.465 \\
(29.14)\end{array}$ & $* * *$ & $\begin{array}{r}0.476 \\
(29.92)\end{array}$ & $* * *$ \\
\hline Industry Concentration $t-3$ & $\begin{array}{l}0.095 \\
(6.43)\end{array}$ & $* * *$ & $\begin{array}{l}0.053 \\
(3.96)\end{array}$ & $* * *$ & $\begin{array}{l}0.044 \\
(3.26)\end{array}$ & $* * *$ \\
\hline AbnormalReturn & $\begin{array}{l}0.001 \\
(0.44)\end{array}$ & & $\begin{array}{l}0.005 \\
(0.45)\end{array}$ & & $\begin{array}{l}0.007 \\
(0.58)\end{array}$ & \\
\hline$R O E$ & $\begin{array}{r}-0.018 \\
-(10.90)\end{array}$ & $* * *$ & $\begin{array}{r}-0.094 \\
-(11.84)\end{array}$ & $* * *$ & $\begin{array}{r}-0.093 \\
-(11.76)\end{array}$ & $* * *$ \\
\hline GrowthMismatch & $\begin{array}{l}-0.009 \\
-(3.09)\end{array}$ & $* * *$ & $\begin{array}{l}-0.045 \\
-(3.39)\end{array}$ & $* * *$ & $\begin{array}{l}-0.041 \\
-(3.08)\end{array}$ & $* * *$ \\
\hline Growth & $\begin{array}{r}-0.0001 \\
-(1.65)\end{array}$ & $*$ & $\begin{array}{r}-0.0003 \\
-(1.46)\end{array}$ & & $\begin{array}{r}-0.0003 \\
-(1.44)\end{array}$ & \\
\hline Liquidity & $\begin{array}{l}0.047 \\
(6.98)\end{array}$ & $* * *$ & $\begin{array}{r}0.390 \\
(11.97)\end{array}$ & $* * *$ & $\begin{array}{r}0.396 \\
(12.18)\end{array}$ & $* * *$ \\
\hline Leverage & $\begin{array}{l}-0.004 \\
-(4.72)\end{array}$ & $* * *$ & $\begin{array}{l}-0.021 \\
-(5.37)\end{array}$ & $* * *$ & $\begin{array}{l}-0.021 \\
-(5.25)\end{array}$ & $* * *$ \\
\hline Size & $\begin{array}{r}-0.001 \\
-(18.68)\end{array}$ & $* * *$ & $\begin{array}{r}-0.006 \\
-(19.07)\end{array}$ & $* * *$ & $\begin{array}{r}-0.006 \\
-(19.20)\end{array}$ & $* * *$ \\
\hline$M T B$ & $\begin{array}{r}-0.0004 \\
-(1.14)\end{array}$ & & $\begin{array}{l}-0.001 \\
-(0.68)\end{array}$ & & $\begin{array}{l}-0.001 \\
-(0.82)\end{array}$ & \\
\hline PERatio & $\begin{array}{r}0.000 \\
-(3.42)\end{array}$ & $* * *$ & $\begin{array}{l}-0.001 \\
-(4.55)\end{array}$ & $* * *$ & $\begin{array}{l}-0.001 \\
-(4.57)\end{array}$ & $* * *$ \\
\hline InstitutionalOwnership & $\begin{array}{l}-0.038 \\
-(8.44)\end{array}$ & $* * *$ & $\begin{array}{r}-0.237 \\
-(11.09)\end{array}$ & $* * *$ & $\begin{array}{r}-0.226 \\
-(10.58)\end{array}$ & $* * *$ \\
\hline $\begin{array}{l}\text { Industry and Year Fixed Effects } \\
\text { Observations } \\
\text { Adjusted } \mathrm{R}^{2}\end{array}$ & $\begin{array}{r}\mathrm{Y} \\
107,727 \\
0.244 \\
\end{array}$ & & $\begin{array}{r}\mathrm{Y} \\
107,727 \\
0.248\end{array}$ & & $\begin{array}{r}\mathrm{Y} \\
107,727 \\
0.252 \\
\end{array}$ & \\
\hline Tests of endogeneity, weak instruments, and ov & ridentificatic & ion: & & & & \\
\hline $\begin{array}{l}\text { Endogeneity Test }(\mathrm{Pr}>\mathrm{Chi}-\mathrm{Sq}) \\
\text { F-Statistic } \\
\text { Partial-R } \\
\text { Sargan-Hansen Test }(\mathrm{Pr}>\mathrm{Chi}-\mathrm{Sq})\end{array}$ & $\begin{array}{r}0.013 \\
1883.720 \\
0.027 \\
0.231\end{array}$ & $\begin{array}{l}* * \\
* * *\end{array}$ & $\begin{array}{r}0.004 \\
2243.360 \\
0.031 \\
0.563\end{array}$ & $\begin{array}{l}* * * \\
* * *\end{array}$ & $\begin{array}{r}0.005 \\
2267.282 \\
0.032 \\
0.441\end{array}$ & $\begin{array}{l}* * * \\
* * *\end{array}$ \\
\hline
\end{tabular}

This table reports results from first-stage OLS regressions instrumenting for customer concentration variables using lagged industry customer concentration. The dependent variables are MajorCustomer, CustomerHHI, and TotalMajorCustomerSales. Industry concentration is measured in year t-2 and t-3 as the average customer concentration within the target SIC 3-digit industry level (excluding the target concentration from the calculation). Industry fixed effects are defined at the Fama-French 48 level. See the appendix for all variable definitions. Continuous variables are winsorized at 1 and 99. T-statistics (reported in parentheses) are based on standard errors clustered at the firm level. *,**, and $* * *$ denote significance at the 10 percent, 5 percent, and 1 percent level, respectively. 
Table 8, cont.

Instrumental variable analysis - Bid likelihood

Panel B: Second stage

\begin{tabular}{|c|c|c|c|c|c|c|}
\hline \multirow{2}{*}{$\begin{array}{l}\text { Dependent variable }=\text { BidIndicator } \\
\qquad \text { Customer Concentration = } \\
\text { Intercept }\end{array}$} & \multicolumn{2}{|c|}{$\begin{array}{c}(1) \\
\text { Major } \\
\text { Customer }\end{array}$} & \multicolumn{2}{|c|}{$\begin{array}{l}(2) \\
\text { Customer } \\
\text { HHI }\end{array}$} & \multicolumn{2}{|c|}{$\begin{array}{c}\text { (3) } \\
\text { Total Major } \\
\text { Customer Sales }\end{array}$} \\
\hline & $\begin{array}{l}-2.172 \\
-(8.90)\end{array}$ & $* * *$ & $\begin{array}{l}-1.830 \\
-(6.85)\end{array}$ & $* * *$ & $\begin{array}{r}-1.857 \\
-(5.71)\end{array}$ & $* * *$ \\
\hline Predicted CustomerConcentration & $\begin{array}{l}-0.523 \\
-(3.94)\end{array}$ & $* * *$ & $\begin{array}{l}-0.114 \\
-(4.46)\end{array}$ & $* * *$ & $\begin{array}{l}-0.110 \\
-(3.73)\end{array}$ & $* * *$ \\
\hline AbnormalReturn & $\begin{array}{l}-0.121 \\
-(4.95)\end{array}$ & $* * *$ & $\begin{array}{l}-0.121 \\
-(5.07)\end{array}$ & $* * *$ & $\begin{array}{l}-0.121 \\
-(5.32)\end{array}$ & $* * *$ \\
\hline$R O E$ & $\begin{array}{l}-0.029 \\
-(1.91)\end{array}$ & $*$ & $\begin{array}{l}-0.030 \\
-(1.80)\end{array}$ & $*$ & $\begin{array}{l}-0.030 \\
-(1.74)\end{array}$ & $*$ \\
\hline GrowthMismatch & $\begin{array}{l}0.003 \\
(0.11)\end{array}$ & & $\begin{array}{l}0.002 \\
(0.09)\end{array}$ & & $\begin{array}{l}0.003 \\
(0.11)\end{array}$ & \\
\hline Growth & $\begin{array}{l}-0.007 \\
-(1.58)\end{array}$ & & $\begin{array}{l}-0.007 \\
-(1.47)\end{array}$ & & $\begin{array}{l}-0.007 \\
-(1.43)\end{array}$ & \\
\hline Liquidity & $\begin{array}{l}0.102 \\
(1.79)\end{array}$ & $*$ & $\begin{array}{l}0.121 \\
(2.08)\end{array}$ & $* *$ & $\begin{array}{l}0.121 \\
(1.84)\end{array}$ & $*$ \\
\hline Leverage & $\begin{array}{l}0.057 \\
(7.45)\end{array}$ & $* * *$ & $\begin{array}{l}0.057 \\
(7.15)\end{array}$ & $* * *$ & $\begin{array}{l}0.057 \\
(8.64)\end{array}$ & $* * *$ \\
\hline Size & $\begin{array}{l}-0.013 \\
-(6.85)\end{array}$ & $* * *$ & $\begin{array}{l}-0.013 \\
-(7.54)\end{array}$ & $* * *$ & $\begin{array}{l}-0.013 \\
-(6.48)\end{array}$ & $* * *$ \\
\hline$M T B$ & $\begin{array}{l}-0.033 \\
-(8.92)\end{array}$ & $* * *$ & $\begin{array}{l}-0.033 \\
-(7.70)\end{array}$ & $* * *$ & $\begin{array}{l}-0.033 \\
-(8.43)\end{array}$ & $* * *$ \\
\hline PERatio & $\begin{array}{r}-0.0008 \\
-(3.55)\end{array}$ & $* * *$ & $\begin{array}{r}-0.0008 \\
-(3.84)\end{array}$ & $* * *$ & $\begin{array}{r}-0.0008 \\
-(3.87)\end{array}$ & $* * *$ \\
\hline InstitutionalOwnership & $\begin{array}{l}-0.063 \\
-(1.52)\end{array}$ & & $\begin{array}{l}-0.071 \\
-(1.63)\end{array}$ & & $\begin{array}{l}-0.069 \\
-(1.63)\end{array}$ & \\
\hline $\begin{array}{l}\text { Industry and Year Fixed Effects } \\
\text { Pseudo } \mathrm{R}^{2} \\
\text { Observations }\end{array}$ & $\begin{array}{r}\mathrm{Y} \\
0.033 \\
107,727 \\
\end{array}$ & & $\begin{array}{r}\mathrm{Y} \\
0.033 \\
107,727 \\
\end{array}$ & & $\begin{array}{r}\mathrm{Y} \\
0.033 \\
107,727 \\
\end{array}$ & \\
\hline $\begin{array}{l}\text { This table reports results from second-stage Logit regressions } \mathrm{r} \\
\text { measures and controls for Compustat firms from 1985-2016. T } \\
\text { TotalMajorCustomerSales are the fitted values obtained in the } \\
\text { are defined at the Fama-French } 48 \text { level. Continuous variables } \\
\text { bootstrapped standard errors. *, }{ }^{* *} \text {, and } * * * \text { denote significanc }\end{array}$ & $\begin{array}{l}\text { ting the pro } \\
\text { dependent } \\
\text { t stage. Se } \\
\text { winsorize } \\
\text { the } 10 \text { per }\end{array}$ & $\begin{array}{l}\text { robabi } \\
\text { t varia } \\
\text { ee the } \\
\text { ed at } 1 \\
\text { ercent }\end{array}$ & $\begin{array}{l}\text { ing a bid to } \\
\text { icator, and } \\
\text { all variable } \\
\text { atistics (rep } \\
\text { id } 1 \text { percent }\end{array}$ & $\begin{array}{l}\text { predi } \\
\text { Major } \\
\text { e defin } \\
\text { orted } \\
\text { t level }\end{array}$ & $\begin{array}{l}\text { omer concentrat } \\
\text { Industry fixed ef } \\
\text { IndustomerHH } \\
\text { heses) are based } \\
\text { ively. }\end{array}$ & $\begin{array}{l}\text { tion } \\
I I, \text { and } \\
\text { affects } \\
\text { d on }\end{array}$ \\
\hline
\end{tabular}




\section{Table 9}

Instrumental variable analysis - Payment method

Panel A: First stage

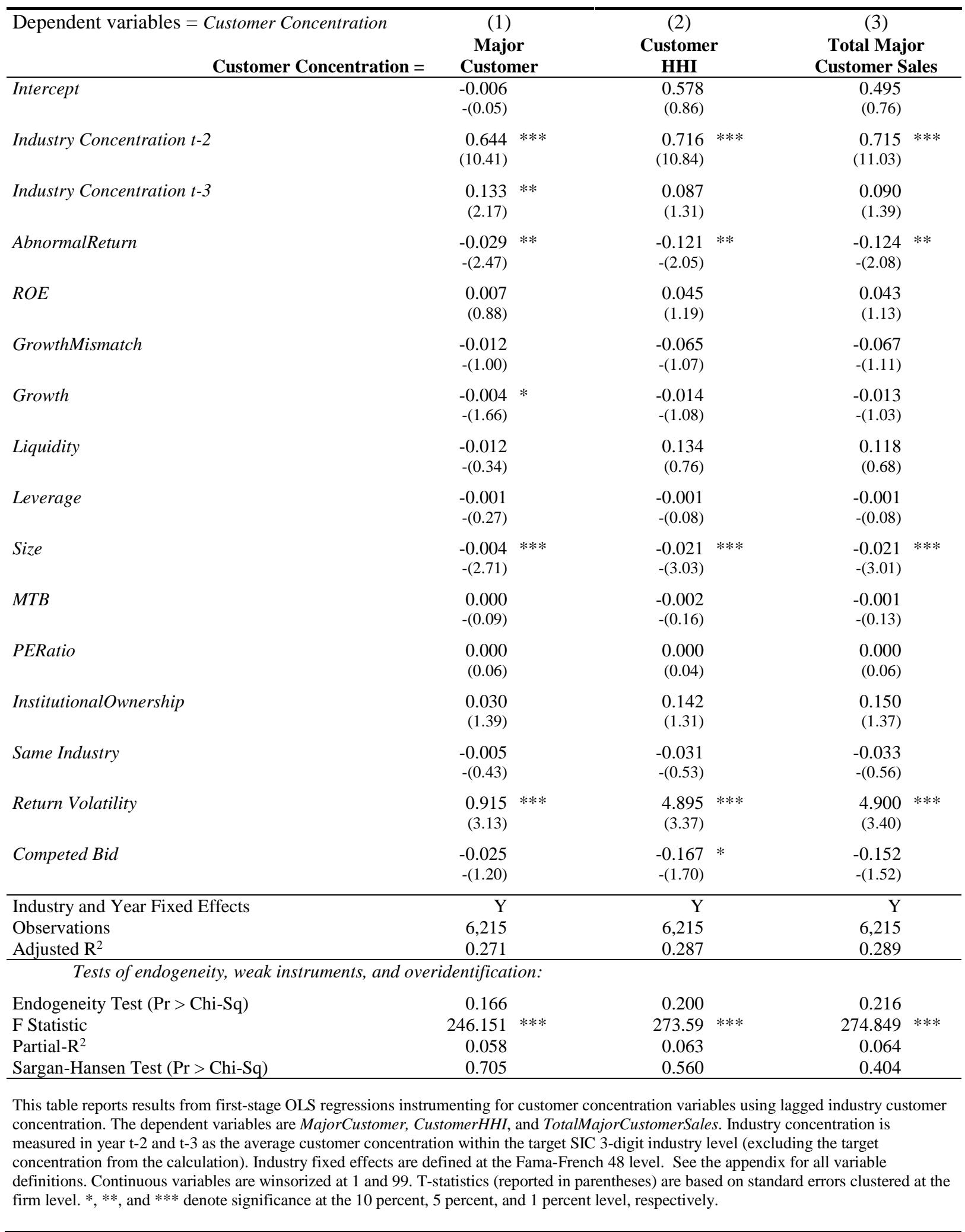


Table 9, cont.

Instrumental variable analysis - Payment method

Panel B: Second stage

\begin{tabular}{|c|c|c|c|c|c|c|}
\hline \multirow{2}{*}{ 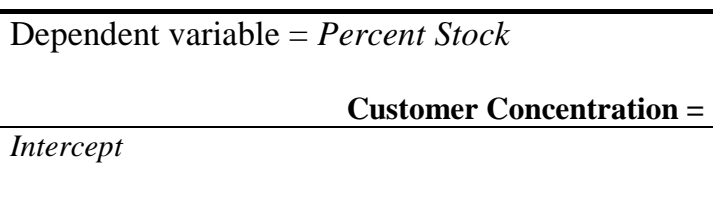 } & \multicolumn{2}{|c|}{$\begin{array}{c}(1) \\
\text { Major } \\
\text { Customer }\end{array}$} & \multicolumn{2}{|c|}{$\begin{array}{l}(2) \\
\text { Customer } \\
\text { HHI }\end{array}$} & \multicolumn{2}{|c|}{$\begin{array}{c}(3) \\
\text { Total Major } \\
\text { Customer Sales }\end{array}$} \\
\hline & $\begin{array}{r}-34.947 \\
-(3.76)\end{array}$ & $* * *$ & $\begin{array}{r}-34.812 \\
-(3.73)\end{array}$ & $* * *$ & $\begin{array}{r}-34.893 \\
-(3.77)\end{array}$ & $* * *$ \\
\hline Predicted Customer Concentration & $\begin{array}{l}1.541 \\
(2.04)\end{array}$ & $* *$ & $\begin{array}{l}1.513 \\
(2.00)\end{array}$ & $* *$ & $\begin{array}{l}1.555 \\
(2.06)\end{array}$ & $* *$ \\
\hline AbnormalReturn & $\begin{array}{l}3.043 \\
(2.96)\end{array}$ & $* * *$ & $\begin{array}{l}2.898 \\
(2.82)\end{array}$ & $* * *$ & $\begin{array}{l}3.049 \\
(2.96)\end{array}$ & $* * *$ \\
\hline$R O E$ & $\begin{array}{l}-0.642 \\
-(0.95)\end{array}$ & & $\begin{array}{l}-0.492 \\
-(0.72)\end{array}$ & & $\begin{array}{l}-0.640 \\
-(0.95)\end{array}$ & \\
\hline GrowthMismatch & $\begin{array}{l}-3.782 \\
-(3.82)\end{array}$ & $* * *$ & $\begin{array}{l}-3.502 \\
-(3.53)\end{array}$ & $* * *$ & $\begin{array}{l}-3.777 \\
-(3.81)\end{array}$ & $* * *$ \\
\hline Growth & $\begin{array}{l}0.353 \\
(1.69)\end{array}$ & * & $\begin{array}{l}0.449 \\
(3.24)\end{array}$ & $* * *$ & $\begin{array}{l}0.352 \\
(1.69)\end{array}$ & $*$ \\
\hline Liquidity & $\begin{array}{l}7.442 \\
(2.77)\end{array}$ & $* * *$ & $\begin{array}{l}8.272 \\
(3.05)\end{array}$ & $* * *$ & $\begin{array}{l}7.468 \\
(2.78)\end{array}$ & $* * *$ \\
\hline Leverage & $\begin{array}{l}-1.303 \\
-(4.72)\end{array}$ & $* * *$ & $\begin{array}{l}-1.266 \\
-(4.59)\end{array}$ & $* * *$ & $\begin{array}{l}-1.304 \\
-(4.72)\end{array}$ & $* * *$ \\
\hline Size & $\begin{array}{l}1.156 \\
(8.40)\end{array}$ & $* * *$ & $\begin{array}{l}1.158 \\
(8.41)\end{array}$ & $* * *$ & $\begin{array}{l}1.157 \\
(8.40)\end{array}$ & $* * *$ \\
\hline$M T B$ & $\begin{array}{l}1.080 \\
(6.35)\end{array}$ & $* * *$ & $\begin{array}{l}1.056 \\
(6.20)\end{array}$ & $* * *$ & $\begin{array}{l}1.080 \\
(6.35)\end{array}$ & $* * *$ \\
\hline PERatio & $\begin{array}{l}0.012 \\
(1.31)\end{array}$ & & $\begin{array}{l}0.012 \\
(1.33)\end{array}$ & & $\begin{array}{l}0.012 \\
(1.31)\end{array}$ & \\
\hline InstitutionalOwnership & $\begin{array}{l}-0.882 \\
-(0.54)\end{array}$ & & $\begin{array}{l}-0.986 \\
-(0.60)\end{array}$ & & $\begin{array}{l}-0.893 \\
-(0.54)\end{array}$ & \\
\hline Same Industry & $\begin{array}{l}14.089 \\
(14.03)\end{array}$ & $* * *$ & $\begin{array}{l}14.143 \\
(14.09)\end{array}$ & $* * *$ & $\begin{array}{l}14.092 \\
(14.03)\end{array}$ & $* * *$ \\
\hline Return Volatility & $\begin{array}{r}15.440 \\
(0.61)\end{array}$ & & $\begin{array}{r}17.999 \\
(0.71)\end{array}$ & & $\begin{array}{r}15.489 \\
(0.61)\end{array}$ & \\
\hline Competed Bid & $\begin{array}{l}-8.655 \\
-(7.05)\end{array}$ & $* * *$ & $\begin{array}{l}-8.743 \\
-(7.11)\end{array}$ & $* * *$ & $\begin{array}{l}-8.680 \\
-(7.08)\end{array}$ & $* * *$ \\
\hline $\begin{array}{l}\text { Industry and Year Fixed Effects } \\
\text { Adjusted } \mathrm{R}^{2} \\
\text { Observations }\end{array}$ & $\begin{array}{r}\mathrm{Y} \\
0.238 \\
6,215 \\
\end{array}$ & & $\begin{array}{r}\mathrm{Y} \\
0.237 \\
6,215 \\
\end{array}$ & & $\begin{array}{r}Y \\
0.239 \\
6,215 \\
\end{array}$ & \\
\hline $\begin{array}{l}\text { This table reports results from second-stage OLS regressions re } \\
\text { controls for bid offers from 1985-2016. The dependent variable } \\
\text { TotalMajorCustomerSales are the fitted values obtained in the } \\
\text { are defined at the Fama-French } 48 \text { level. Continuous variables } \\
\text { standard errors clustered at the firm level. *, **, and *** denot }\end{array}$ & $\begin{array}{l}\text { sing the pay } \\
\text { s Percent } S t \\
\text { rst stage. Se } \\
\text { re winsorize } \\
\text { significance }\end{array}$ & $\begin{array}{l}\text { ymen } \\
\text { Stock, } \\
\text { ee the } \\
\text { ced at } \\
\text { e at th }\end{array}$ & $\begin{array}{l}\text { oredicted cus } \\
\text { ustomer, Cus } \\
\mathrm{r} \text { all variable } \\
\text { tatistics (rep } \\
5 \text { percent, a }\end{array}$ & $\begin{array}{l}\text { stomer } \\
\text { stomer } \\
\text { defin } \\
\text { ported } \\
\text { and } 1\end{array}$ & $\begin{array}{l}\text { entration measures } \\
\text { and } \\
\text { Industry fixed eff } \\
\text { rentheses) are base } \\
\text { t level, respectivel }\end{array}$ & $\begin{array}{l}\text { s and } \\
\text { eects } \\
\text { ed on } \\
\text { ly. }\end{array}$ \\
\hline
\end{tabular}

